\title{
Sixth International Symposium on the Ordovician System
}

\author{
Sydney, Australia, 15-19 July 1991
}

The Subcommission on Ordovician Stratigraphy of the International Commission on Stratigraphy (International Union of Geological Sciences) has been sponsoring regular meetings on the Ordovician System since the Subcommission's inception, but none of these previously has been held in the Southern Hemisphere. This deficiency was remedied admirably this past July when over 60 scientists traveled to Australia for the Sixth International Symposium on the Ordovician System (VI ISOS), which was chaired by Barry Webby of the University of Sydney. The meeting comprised four presymposium excursions in eastern Australia, 5 days of technical sessions at the David Edgeworth Building in the Department of Geology and Geophysics at the University of Sydney, New South Wales, and one postsymposium excursion south to Victoria.

The week's technical presentations were divided into sessions on chronostratigraphy (convened by Roger Cooper, New Zealand, and Stig Bergström, USA); paleoenvironmental and paleogeographic reconstructions (convened by Bob Nicoll, Australia, and Bob Elias, Canada); event stratigraphy, volcanism, and tectonics (convened by David Bruton, Norway, and Bob Neuman. USA): and economic deposits (convened by Fons VandenBerg, Australia). In addition to these. a number of poster displays were presented. and Subcommission workshops and meetings were held every evening.

The session on chronostratigraphy was wide ranging and of particular interest in light of the Series Working Groups of the Subcommission and the Working Group on the Cambrian-Ordovician Boundary. Presentations included aspects of geochronology and the use of biostratigrahy in defining boundaries: other papers related to this problem also were delivered in the session on event stratigraphy. The topical concern of "one person"s chrono- is another person"s bio-" was somewhat in evidence, but most Ordovician stratigraphers now seem well aware of the pros and cons of each method of definition, and all-or certainly a large majority - apparently consider retention of both global and local chronostratigraphic units to be invaluable.

Zircon-based geochronology from bentonites and its use in the cross-correlation of biozones, chronostratigraphy, and global physical events were discussed in both the chronostratigraphy and event stratigraphy sessions. However. the contradictory ages given by Australian researchers who use a single-grain, ion probe method versus those who employ the multigrain, mass spectrometer isotope dilution technique will have to be resolved before an unequivocal set of precise ages can be accepted for the divisions of the Lower Paleozoic. Other problems raised during the chronostratigraphy session were related to the apparently contradictory ranges of graptolite taxa found in nearshore and offshore facies; some seem to have evolved in open ocean before migrating subsequently into more shallow areas. where they apparently survived longer than those that remained in the deeper areas where they first appeared. Such a phenomenon seems to be supported by renewed recognition of depth and depth-related factors 'being the dominant influence, rather than latitudinal variation, in controlling graptolite distribution during the Ordovician

The session on paleoenvironmental and paleogeographic reconstructions centered more or less on the use of faunal provincialism in the recognition of ancient continental and oceanic masses. It was interesting to observe the number of variations in detail, particularly for northwestern Europe and eastern North America, although the overall picture of Iapetus and its margins seems to have aged into respectability. Less controversy apparently surrounds the Australasian reconstructions: was this a reflection of bet ter understanding or of fewer presentations? The session on economic deposits was relatively short but offered an interesting comparison of Ordovician hydrocarbon occurrences in Australia. North America, and Estonia, together with a summary of the structural control of gold deposits in the gold belt of central Victoria, southeastern Australia.

Evening workshops concentrated mainly on the progress made by the working groups that were established during the Fifth International Symposium in St. John's, Newfoundland. Canada. The aim of these working groups was to recommend global series and suitable stratotype sections for the divisions of the Ordovician System. A majority of Ordovician stratigraphers seem to prefer a sixfold division for the system, although appropriate names and boundary horizons have not been decided upon in most cases. The base of the lowermost series will depend on the definition of the base of the Ordovician, which is under consideration by the Working Group on the Cambrian-Ordovician Boundary. During the workshop to discuss the progress made by this group, participants made it very clear that they felt that more than enough time and effort had been spent on this problem and that either of the two short-listed sections (Green Point, Canada, and Dayangcha, China), while not perfect, would be suitable as a Global Stratotype Section. Participants pointed out several times that in real rock there is no such thing as a "perfect" section and that these two localities probably are the most complete that exist anywhere in the world. Most members of the second series working group were in favor of a lower boundary for that interval at the base of the Tetragraptus approximatus Biozone, as defined on graptolites, although the name to be adopted for the series (approximating the widespread use of the Arenig Series) and suitable stratotype section have yet to be decided. The debate on whether the third series should be placed at a horizon near the base of the Whiterock series of the USA or at the base of the Llanvirn of the UK was still very much open. Possible graptolitic levels for these horizons include positions at or near the base of the Isograptus victoriae Biozone, as well as the incoming of the distinctive diplograptid and glossograptid fauna, or the base of the Didymograptus artus Biozone, respectively. The definition and names for the remaining series of the Ordovician are also still open to discussion. Although divisions for the upper part of the Ordovician clearly are needed. few global physical or evolutionary events occurring at suitable horizons could be used, and it is probable that "quiet" biostratigraphic boundaries will need to be employed.

A number of more relaxed social events were scattered throughout the program and provided a welcome relief to the 14-hour days of the technical sessions. The entire Wednesday was dedicated to a combined excursion of local Triassic geology and sightseeing (led by David Branagan and Armstrong Osborne), plus a most popular visit to feed kangaroos and play with koalas at a local animal reserve. The day was rounded off with a spectacular symposium dinner aboard a luxury cruiser on Sydney Harbor. The only problem with such accommodation was that nobody was quite sure whether it was the increased swell or some other unknown effect that was causing us to 
sway by the end of the evening. The final Chinese banquet on the last day at a restaurant in the heart of Chinatown was delicious, but few people seemed sufficiently awake after the intensive week to make the most of it.

A selection of papers presented during the technical sessions will be published and should be available by early 1992 (the proceedings volume of the V ISOS at St. John's. Newfoundland, edited by Chris Barnes and Henry Williams, is now available as Paper 90-9 from the Geological Survey of Canada).

The four presymposium excursions were to the Great Barrier Reef. Black Mountain in Queensland. Amadeus Basin in Northern Territory, and New South Wales. The first of these was run in conjunction with, and numerically dominated by, the "Friends of the Ostracods." It was centered on Heron Island at the University of Queensland's field center, the 80-km catamaran trip from the mainland being accompanied by gale-force winds, rain, and some very green faces. Such problems were soon, however, forgotten; for those not proficient in snorkelling or scuba diving, Heron Island is ideal for reef walking in knee-deep water at low tide across the reef flat to reef rim, a distance of about $500 \mathrm{~m}$. A trip in a semisubmersible along the reef slope provided staggering views of corals and colorful fish. Guidance through the plethora of animal and plant life was given by an enthusiastic John Jell, who was ably supported by Ed Frankel and Jane Hall.

The trip to Black Mountain (Mt. Unbunmaroo) in western Queensland provided an opportunity to visit and evaluate new information from the thickest known carbonate-platform sequence spanning the Cambrian-Ordovician boundary. John Shergold, John Laurie, and Bob Nicoll deserve considerable credit for a superbly organized excursion and, more importantly, for their years of painstaking research on trilobite assemblages and conodont faunas. The trilobites have allowed detailed correlation with Asian sequences, whereas the conodont succession may constitute the world's most complete such succession across the interval. Several horizons were suggested to represent significant eustatic events, which may well be important in global correlation. and it might prove of use if a dedicated sedimentologist could be coerced into working up a detailed lithofacies analysis. Participants left Black Mountain in awe of the thickness of the sequence but disappointed with the scarcity of trilobites (and complete lack of graptolites) in the peritidal facies that dominates the boundary interval. Nonetheless, the good recovery of conodonts and proven potential for magneto- and chemostratigraphy assure a prominent role for the section in refining global chronostratigraphy and in producing a more tightly constrained early Paleozoic sealevel curve.

For those who are used to working in thin, condensed successions of "shelly" and "graptolitic" facies, the 2,000-m thick Ordovician siliciclastic sequence and its economically important oil and gas reserves of the Amadeus Basin were something different. The Macdonnell Ranges both east and west of Alice Springs provided staggering redrock scenery, including Gosses Bluff, a 20$\mathrm{km}$-across meteorite impact crater and national monument, every bit as impressive as Ayers Rock. Participants slept under the stars in not-always-warm sleeping bags (swags), but the cold nights were made up for by the food, which was provided by the owner and driver of a solid $4 \times 4$ bus "Brutus," and a good deal of fireside humor. Bob Nicoll, John Laurie, John Shergold, Monica Young, and colleagues from the Bureau of Mineral Resources, Geology and Geophysics and the Northern Territory team did a tremendous job in putting the trip together for a group of 25 people, which included some enthusiastic, fee-paying amateurs.

The award for the wettest trip went to the New South Wales excursion, where participants formed a Lamington Club, membership requiring ingestion of large amounts of that famous Australian cookie. Barry Webby, Laurie Sherwin, Ian Percival, and Doon Wyborn skillfully guided the party through an assortment of sediments, volcanic formations, and diverse fossil assemblages in the Cowra trough and in Orange and Parkes. western New South Wales. Clearly, an excellent, interdisciplinary job had been done on basinal analysis, which permits an unusually clear understanding of a complex marginal sequence. Highlights (for the paleontologists) included several fossil stops and a most memorable barbeque lunch provided by the Barnes of Nelungaloo Station.

The postsymposium excursion to Victoria, ably led by Fons VandenBerg and Ian Stewart, was the dream of every Ordovician graptolite worker. The 12 participants were treated to an excess of beautifully preserved material from one of the world's classic areas for Ordovician graptolites. Fons' driving was admired by all-including a demonstration of how to turn a Toyota minibus into a $4 \times 4$ vehicle on the mountain road to Enoch's Point (was it eight or nine times we had to push?) - as was Ian's adeptness at extracting enormous blocks of black shale by using a portable jackhammer. In addition to examining representatives of most Victorian stages, a few equally popular nongraptolite stops included Permian tillites and a trip down a restored gold mine at Bendigo. The success of the trip was demonstrated not only by the lively discussions and arguments at each outcrop but also by the sheer number of boxes dumped on an unsuspecting post office in Gisborne at the end of the trip!

Barry Webby and his committee are to be congratulated for their splendid organization of the meeting, which seemingly ran without a hitch. The final date and venue for the VII ISOS are as yet undecided, but we all look forward to yet another successful meeting where we will discuss what is, after all, the most important period of geological time. $\square$

\section{Henry Williams}

Department of Earth Sciences Memorial University of Newfoundland St. John's, Newfoundland AlB 3X5. Canada

(With assistance in excursion reports from David Bruton, Barrie Rickards, and John Tavlor) 


\section{International Congress on the Permian System of the World}

\section{Perm', USSR, 5-10 August 1991}

It was cold; it was rainy; it was August in the foothills of the Ural Mountains. Yet no warmer friendships could be found than those between Soviet geologists and their guests from throughout the outside world. After nearly 2 weeks of camaraderie on outcrops of the Southern Urals on a Congressrelated field excursion, we were as close as neighbors anywhere. We had become lifelong friends, even though we could scarcely communicate in broken English and a scattering of Russian. Chinese, German, Polish, Hungarian, and Iranian languages. Our communications were from the heart, regardless of the political boundaries crossed. It was in this setting that some 400 geologists from throughout the world gathered in Perm: USSR (Russia), in order to commemorate the 150th anniversary of the Permian System on August 5-10, 1991.

In a letter to Czar Nicholas I written in 1841. Sir Roderick Murcheson designated his new Permian System, which was to include:

... the chief deposits of gypsum of Arzamas, of Kazan. and of the rivers Piana, Kama, and Oufa, and of the environs of Orenbourg; we also place in it the saline sources of Solikamsk and Sergiefsk, and the rock salt of Sletsk and other localities in the government of Orenbourg, as well as all the copper mines and the large accumulations of plants and petrified wood of which you [Fischer de Waldheim] have given [in] a list in the "Bulletin" of your Society (anno 1840). Of the fossils of this system, some undescribed species of Producti might seem to connect the Permian with the Carboniferous aera: and other shells, together with fishes and saurians, link it on more closely to the period of the Zechstein, whilst such peculiar plants appear to constitute a flora of a type intermediate between the epochs of the new red sandstone or "trias" and the coal measures. Hence it is that I have ventured to consider this series a "system."

Thus, the originally defined Permian System included only the now-recognized Kungurian, Kazanian, and Tatarian Stages, or middle and Upper Permian. The boundaries are still in dispute after 150 years, especially at the base of the system.

Five days of papers presented in five consecutive sessions addressed differences of opinions from all continents. Although interpretations varied wildly, we came away with mutual respect and a feeling of global singularity. The multitude of problems regarding the Permian System has been aired openly for the first time. In all, 268 papers were presented and discussed with enthusiasm. The presentations grouped into Section I, "Paleontology and Biostratigraphy of the Permian System," in which the boundary problems were discussed, were translated simultaneously into the Russian and English languages. Other sections addressed problems of (II) "Regional Stratigraphy and Biostratigraphy," (III) "Sedimentation, Depositional Environments, and Paleogeography," (IV) "Tectonic and Paleotectonic Reconstruction, Magmatic Processes, and Mineral/ Energy Resources," and (V) "Karst Processes, Environmental/Conservation Problems."

The first step taken to resolve the lower boundary controversy was at a meeting of the Working Group of the Permian System in Perm' on August 9, when a formal proposal was made on behalf of the Russian geologists by Dr. Vladimir I. Davydov. He requested that the International Commission on Stratigraphy consider formally accepting the Aidaralash section in the Southern Ural Mountains east of Aktyubinsk, Kazakhstan. between beds 19 and 20 , as the stratotype section for the Carboniferous-Permian boundary. This is the Orenburgian-Asselian boundary established by V.E. Ruzhenzev, the founder of the Asselian Stage, at the base of the Sphaeroschwagerina vulgaris$S$. fusiformis fusulinid biozone. Conditions of acceptance included statements that exposures at the Aidaralash section would be improved artificially and that the locality would be forever preserved and open to sample collecting by geologists from all nations. That proposal was approved overwhelmingly by the interested attendees of the working group. There were those who were skeptical, however, of the 297 fusulinid species and subspecies listed in the Aidaralash section.

To reach a consensus of international friendship in Perm' was not easy. Attendees received endless instructions for travel to and within the USSR, none of which proved practical. By hook and by crook we somehow gathered in Perm' on the Kama River in generally good spirits. Having met and conquered all possible obstacles was a boost to our egos, and the overwhelming kindness and helpfulness of our Russian hosts was never ending. Our desires to open new avenues of communication met with open arms. We exchanged books, reprints, mailing addresses, and promises of future exchanges of information with enthusiasm. In the words of Igor Barskov in one of numerous banquet toasts, ". . . this was the first, but certainly not the last, International Congress on the Permian System."

Drs. Boris I. Chuvashov and Alan E.M. Nairn and their respective committees are to be congratulated on a most successful conference held in spite of overwhelming and ever-changing obstacles. Whether or not lasting conclusions were reached will be determined by history. Regardless, this was a first step in international relationships for solving ubiquitous problems of the most controversial of all geologic systems. May these inroads into international communications forever remain as open and cordial as they were at the close of this most productive Congress. If we could all sit down under a canvas canopy in a field camp beside the Ural River to discuss our differences over a hot cup of "chai" (Russian tea), international fears and distrust would evaporate in the breeze. $\square$

\section{D.L. Baars}

Kansas Geological Survey

Universit of Kansas

1930 Constant Avenue, Campus West Lawrence, Kansas 66047-2598, USA 


\title{
Saline lakes (a contribution to IGCP Project 219)
}

\author{
Saskatoon, Saskatchewan, Canada, 6-21 August 1991
}

An interdisciplinary group of about 70 geologists, hydrologists, biologists, and ecologists, mostly from North America and Europe, met in Saskatoon, Canada, in the middle of August 1991 to discuss the sedimentary and paleolimnological record of saline lakes. The conference was organized as a contribution to International Geological Correlation Programme (IGCP) Project 219 (Comparative Lacustrine Sedimentology in Space and Time) and was convened by Robin Renaut (University of Saskatchewan), Doug Stead (University of Saskatchewan), Bill Last (University of Manitoba), and Bernie Owen (Hong Kong Baptist College). The meeting consisted of a 6-day preconference field trip to the little-known saline lakes of the interior of British Columbia, a 1-day field excursion during the meeting to saline lakes near Saskatoon, Saskatchewan, and a 5-day postconference field trip to the saline lakes of the Canadian Great Plains in southern Saskatchewan.

\section{Preconference field trip}

This field trip was led by Robin Renaut (who was also the main organizer of the meeting) with the help of Doug Stead and Bernie Owen. The participants on the trip met in Kamloops, British Columbia, on 5 August, a day before we were to set out. This allowed the overseas travelers a chance to acclimatize and to meet the other participants. The next day, 18 scientists and one 3-month-old baby set out from Kamloops eager to explore the diversity of saline lakes in the Cariboo Plateau near Clinton, British Columbia.

During the morning of the first day, we visited some of the exposures of glacial Lake Kamloops that crop out east of town. Although not a saline lake, the huge exposures of presumably deltaic sand and mud were a good reminder - to those of us who study little evaporitic ponds - of the types and scale of deposits that are found in truly large lakes.

In the afternoon, the field trip headed to the little-known saline lakes of the Cariboo Plateau near Clinton. These lakes are spectacular in the diversity of water chemistries and evaporite minerals that are present in such a small geographic area. Unfortunately, the weather did not always cooperate with the planned itinerary, but after some re- arranging, we managed to see, in the course a few days, about 10 of the hundreds of saline lakes in the area.

The lakes range from freshwater bicarbonate lakes precipitating stromatolitic sediments (fig. 1) to hypersaline $\mathrm{Mg}-\mathrm{Na}-\mathrm{SO}_{4}$ lakes that precipitate epsomite, bloedite, and mirabilite salts. Of particular interest to the group were the strange circular sediment patterns in Clinton and Last Chance Lakes that separate each lake into small brine pools, the high abundance of magnesiumrich carbonate sediments (dolomite, hydromagnesite, and magnesite), and the seasonal variation in temperature, which plays an important part in evaporite mineral precipitation, sediment particle formation, and sediment redistribution. Many of the participants are used to saline lakes in hot, harsh climates. These lakes produce large quantities of evaporite minerals in cold, harsh climates, where winter temperatures may dip below $-40^{\circ} \mathrm{C}$.

After the lakes of the Cariboo Plateau, we visited the Basque Lakes, noted for their abundance of primary precipitated dolomite (fig. 2). These lakes are similar to other Mg$\mathrm{Na}-\mathrm{SO}_{4}$ lakes in the Cariboo Plateau, except that they are a bit smaller and perhaps a little more thoroughly studied.

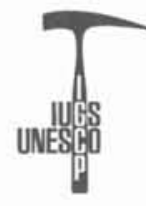

The field trip ended with a long but thoroughly enjoyable drive through the Rocky Mountains and Alberta. We took in such sights as Lake Louise, Banff National Park, and the Royal Tyrrell Museum of Paleontology and dinosaur badlands at Drumheller, Alberta.

The field trip was well paced and relaxed and had something for the biologists, as well as for the hydrogeologists. Discussions were lengthy and informal, and Robin Renaut always was willing to be flexible and to accommodate the wishes of the group. This flexibility was important because, owing to the wetter than usual spring weather, many of the normal salt crusts had not formed on the lakes. This made viewing and sampling many of the lakes difficult.

\section{The conference}

The conference itself took place in the beautiful confines of the University of Saskatchewan campus. Nearly 40 talks and 12 poster sessions were given in the 3-day conference on a variety of topics concerning both modern and ancient saline lakes. After some interesting opening remarks by the new Dean of Arts and Sciences at the University of Saskatchewan, the meeting began with some introductory remarks by Bill Last. He

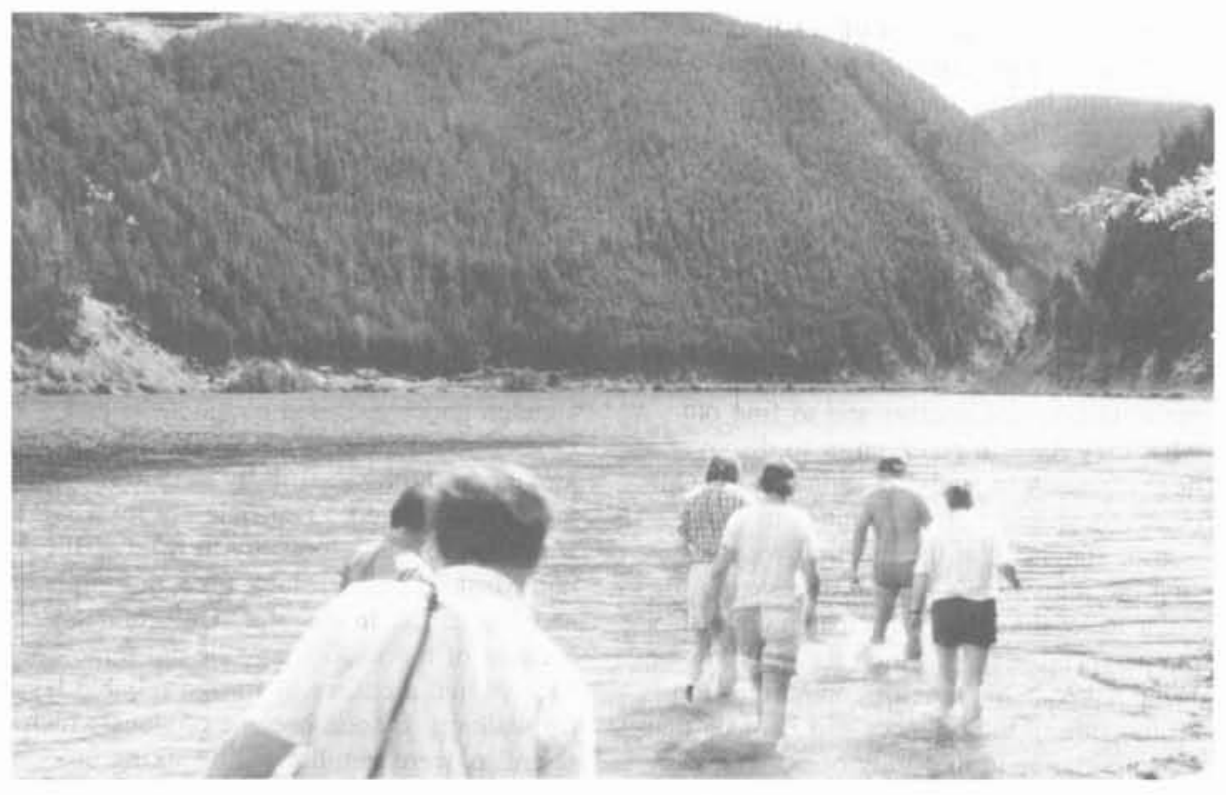

Figure 1. - Preconference field trip participants braving the cool waters of Kelly Lake in order to view Canada's only known occurrence of modern lacustrine stromatolites. The change in the shading of the water indicates the edge of the stromatolite shelf. 


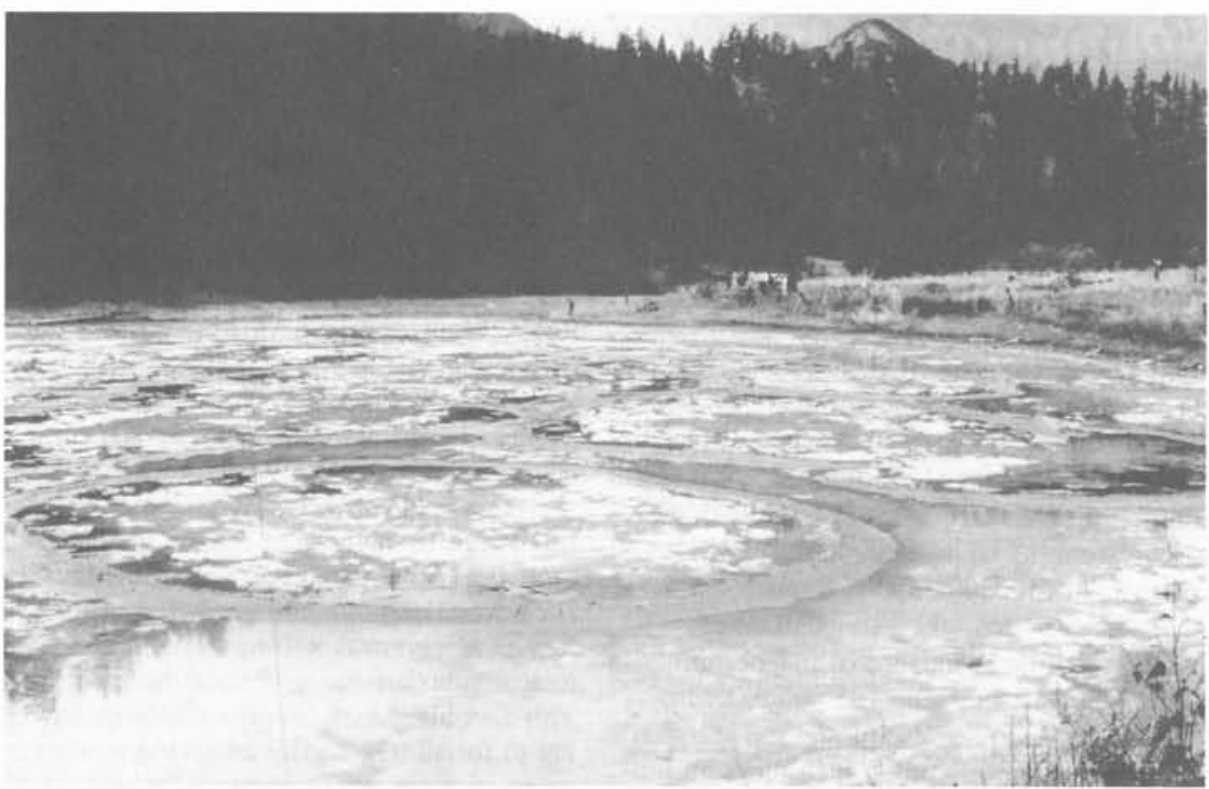

Figure 2.-One of the saline Basque Lakes in British Columbia, Canada, showing the circular patterns of carbonate mud diapirs that isolate areas of the brine. Bittern salts precipitate in the depressions between the mud. The origin of the mud diapirs is under debate. Field trip participants and van are in the distance.

explained that the meeting was broken into four broad categories. There were to be 13 presentations on "Sedimentation, Geochemistry, and Diagenesis in Modern Saline Lake Basins," 10 papers on "Pleistocene and Holocene Saline Lakes of North America," 5 papers on "Pleistocene and Holocene Saline Lakes Outside North America," and, finally, 8 papers on "Saline Lakes in the Geological Record." Because of the diversity of papers presented and the number of subdisciplines represented, a summary of the presented papers would be impossible without an extremely detailed description.

Indeed, if one were to try to find any flaw in this well-run meeting, it would be the lack of a common theme or goal. However, this would be contrary to the organizers' effort to pull together people of different backgrounds who study different aspects of saline lakes. The idea was to get these people to talk to one another and to find out what they have in common or to discover a new approach to studying saline lakes. One of the most common beginnings to a question or statement at the meeting was to state first the individual's branch of research in order to let the other participants understand the perspective from which the question was being asked. This type of communication is all too rare in the sciences and is of particular importance in the study of saline lakes because they make up such a diverse system.
Copies of the abstracts for the meeting are available from Robin Renaut for those who are interested. Copies of the field trip guides may be available at some cost. Inquiries should be directed to Robin Renaut for the preconference field trip and to Bill Last for the field trips during and after the conference.

\section{Within-conference field trip}

The within-conference field trip was led by Bill Last. This trip was designed to give the participants a taste of the large, deep saline lakes around the Saskatoon area of Saskatchewan. Even with the promised early start and fast pace, nearly all the conference participants decided to go on this trip. Unfortunately, the weather again decided not to cooperate, and we ended up spending more of the morning discussing the lakes, while we huddled under enclosed picnic areas and swatted mosquitoes, than we actually spent looking at the lakes. But by the afternoon, things had cleared up sufficiently for a number of brave souls foolishly to follow Bill into Muskiki Lake to look for a pit that he had dug earlier in the year. Unfortunately, because of the wet spring, the epsomite crust had not had a chance to form a reliable layer for walking. It soon became obvious which scientists were familiar with walking on weak salt crusts and which individuals would be paying the price later for such foolish ness. As individuals broke through the crust with each step, the sharp crystals of epsomite dug into his/her shins. Combined with the suction of the mud, which made it difficult to pull one's feet out, it became a painful nightmare of bloody shins and muddy clothes. Needless to say, we never made it to the pit. Bill and a few other seasoned salt. crust walkers had the technique down and had hardly a scratch, but the rest went back to Saskatoon nursing some nasty cuts.

All in all, the trip was a success, even though we had to miss a few lakes owing to the weather and the time constraints. The lakes around the Saskatoon area are much deeper and have a larger surface area than the saline lakes of British Columbia. Although the hydrology is different, the chemistries of the waters are similar to those of the British Columbian lakes (mainly $\mathrm{Na}-\mathrm{Mg}$ $\mathrm{SO}_{4}$ ), and the types of evaporite minerals are also similar. But what makes these lakes important is the fact that these lakes are comparable to deep-water evaporites in the geologic record, and they can be used potentially as analogs to ancient saline lake systems without much difficulty.

\section{Postconference field trip}

Bill Last also led a successful postconference field trip to the saline lakes of southern Saskatchewan. The trip was attended by 20 people and ran at a very lively pace. Bill showed the participants a range of deep sulfate lakes and playas in an area that is in stark geomorphic contrast to the area of the saline lakes of British Columbia.

\section{Concluding comments}

In summary, the meeting and field trips achieved their purpose of communication and laid the foundation for some collaborative work that might not have been possible without this contact. The organizers of the conference, in particular Robin and Bill, should be commended for a well-run, relaxed meeting and for interesting field trips, during which important scientific exchanges were accomplished. $\square$

\section{Michael R. Rosen}

Division of Water Resources

Commonwealth Scientific and Industrial Research Organization

Private Bag

P.O. Wembley 6014

Western Australia 


\title{
Microvertebrate hunting in Québec
}

\author{
Miguasha, Québec, Canada, 9-22 June 1991
}

The Seventh International Symposium on the Studies of Early Vertebrates (SEVS) took place at the Parc de Miguasha, Québec, in June 1991. Held at the height of the fine lobster season in the Maritime Provinces (an added bonus), it was well attended by some 60 participants from 12 countries, including 4 Palaeozoic fish experts from Australia.

The Parc de Miguasha houses a museum and collections representing the classic Late Devonian (early Frasnian) fish fauna of the Escuminac Formation, known for the past 150 years as one of the most fascinating fossil sites. For many, it was their first chance to see this fine example of a small theme museum and research establishment dedicated to the preservation and enhancement of the fauna and flora of one geological sequence. M. Marius Arsenault (Canada), Director of the park and President of the symposium, was true to his word, for he had invited people during the last SEVS in Beijing, China, in 1987 to come to Québec. He and his Government pulled out all the stops and even enhanced the facility by adding a brandnew (Can\$1.7-million) conference hall and a small restaurant, aptly named the "Devonian."

The Escuminac Formation is exposed east and west of Miguasha Wharf near Nouvelle on the south coast of the Gaspé Peninsula (fig. 1), close to the contact between Chaleur Bay and the Ristigouche River. Liv- ing in the presumed coastal marine environment of the time were eurypterids, scorpions, conchostracans, and various trace fossilforming invertebrates, as well as a rich fauna of fish (osteostracans; anaspids; placoderms; acanthodians; Cheirolepis representing the actinopterygians, coelacanths, rhipidisians, osteolepiforms, and lungfish; and the panderichthyid, Elpistostege). Plants and spores also are prevalent (Vezina and Cloutier. 1991). Since the first discovery of fossils by a New Brunswick Survey geologist in 1842 , the site has been scoured by professionals and amateurs, including members of the local Plourd family, their name now immortalized in the placoderm genus Plourdosteus. Eminent geologists and paleontologists Whiteaves and Dawson (of Canada), Smith Woodward, Stensiö, Romer, Denison, Thomson, Westoll, Schultze, Dineley, Williams, and especially Jarvik have been instrumental in making this one of the most famous and well-worked sections in the Palaeozoic. Professor Erik Jarvik's (Sweden) work on the sarcopterygian fish, Eusthenopteron foordi, has contributed to our understanding of the phylogenetic relationships of fish and early tetrapods, and the site is a key one in the continuing debate on marine or nonmarine origins of these faunas and the sediments enclosing them.

The symposium was opened officially at a banquet on June 9 that was attended by $M$.

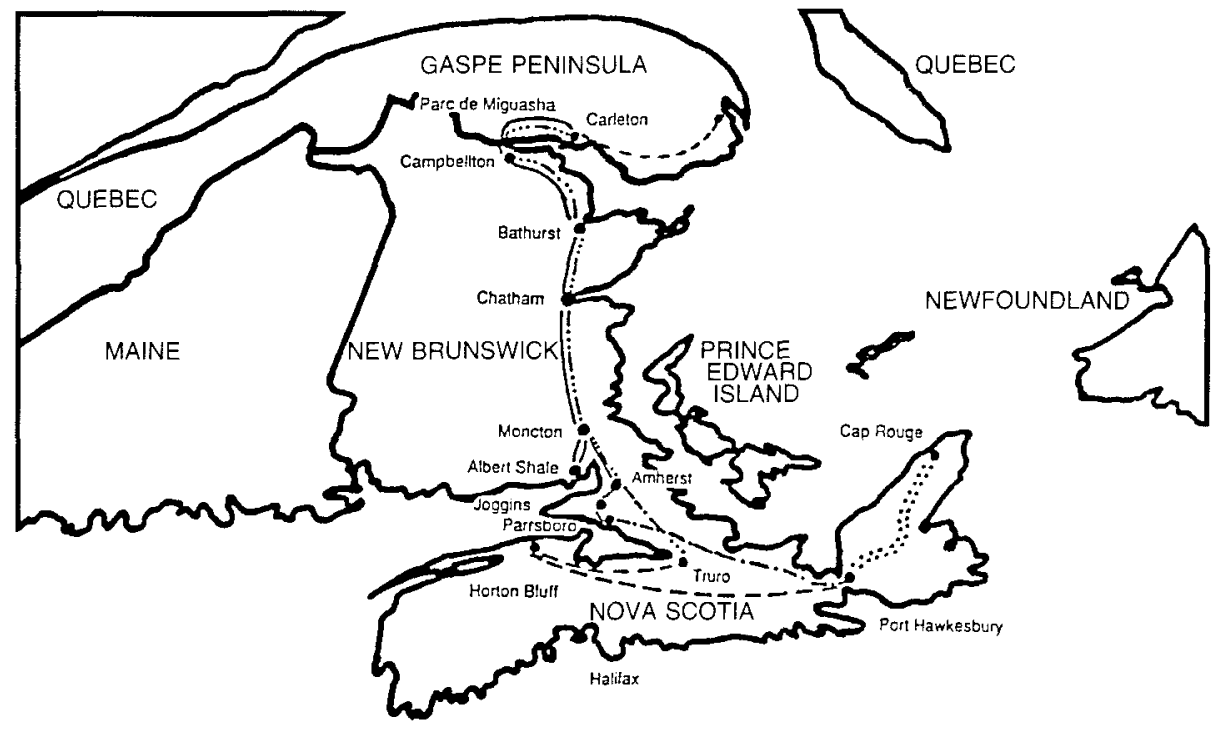

Figure 1. - Location of Parc de Miguasha on the Gaspé Peninsula of Québec, Canada, and the field trips run on the peninsula and through the Maritime Provinces of Canada.
Gaston Blackburn, Ministre du Loisir, de la Chasse et de la Pêche of Québec, the ministry that controls the conservation park. The occasion honored the revered palaeoichthyologist, Professor Jarvik, now aged 84, who was named President d'Honneur de Symposium because of his exceptional contribution to vertebrate paleontology. Similarly honored was M. Rene Bureau, a Québecer who has been instrumental since 1937 in promoting the formation of the Parc de Miguasha in order to protect and preserve the site. During the proceedings, Marius Arsenault formally announced the award from the United $\mathrm{Na}$ tions Educational, Scientific, and Cultural Organization (UNESCO) and the International Union of Geological Sciences (IUGS) for International Geological Correlation Programme (IGCP) Project 328 on Palaeozoic microvertebrates.

The balmy sea resort of Carleton provided an excellent venue for this symposium, which was an opportunity to meet with colleagues, including for the first time nearly all the world's thelodont experts, as well as some new students and others who had not previously attended symposiums on early vertebrates. Over 4 days, 42 papers were presented (Vezina and Arsenault, 1991), about which a symposium volume will be published by the University of Kansas (USA). The discourse got off to a good start as Dr. Dick Jeffries (USA) extolled the virtues of the calcichordates, which, for many, still have more relevance to echinoderm phylogeny than to vertebrate phylogeny. As the late Beverly Halstead once remarked, "A vertebrate with its brain wrapped round its rectum ain't going to get far." Mark V.H. Wilson (Canada) unveiled a startling array of new Silurian and Devonian thelodonts from the Mackenzie district of Arctic Canada. This array forces a complete rewrite of our knowledge of these rather enigmatic, little agnathan fish that have come to prominence for their biostratigraphic usefulness in recent decades. Remarkably similar, new Early Silurian microvertebrate faunas, including thelodonts and some of the oldest shark remains, were reported in sessions by Sue Turner (Australia) and Valya Talimaa (Lithuania) from the local Québec rocks, New Brunswick, and Nova Scotia, as well as from further afield in Siberia. A fascinating coincidence of discovery came to light when it was realized that Wilson, Tiiu Märss (Estonia), Alex Ritchie (Australia), Jo Vergoossen (Netherlands), and Wim van der 
Brugghen (Netherlands) all had new evidence of specialized branchial scales in their thelodont material from Canada and Scotland. Other agnathans that were discussed included the unusual Ordovician heterostracan-like forms from central Australia (Ritchie) and Bolivia. Pierre-Yves Gagnier (Canada) concluded that these early Gondwanan agnathans, such as Arandaspis and Sacabambaspis, were more closely related to one another than to the Northern Hemisphere astraspids. Are we dealing here with two separate origins for vertebrates, one or both of which foundered during the climatic changes in the Late Ordovician and left the field open for other vertebrate groups that have only been hinted at so far in earlier times?

Another main theme sprang from the nature of the Miguasha fauna as a result of discussions on the form and relationships of advanced jawed fishes, prototetrapods, and early tetrapods. Patricia Gensel (Canada) gave us an overview of the Late Devonian flora, especially that from Miguasha. Other papers on the Escuminac fauna included $G$. Arratia (USA) and R. Cloutier's (Canada) major reassessment of the morphology of Cheirolepis canadensis and Cloutier's attempt to quantify the intraspecific variation of Scaumenacia curta on the basis of over 1,000 specimens, so rich is the Miguasha site. Cloutier also used computer-driven cladisitic analysis in order to try to sort out the relevance of the dipnoan palatal bones, although the answers did not seem altogether to satisfy other dipnoan workers who were present. E. Hitchcock (Canada) braved the lions in their den by providing a new functional interpretation of the skull and neck movements in Eusthenopteron.H-P. Schultze (USA) and Cloutier presented a major study of the Escuminac fauna by comparing it with faunas from other key Frasnian sites worldwide, and this provided us with an important data base for paleobiogeographic studies. P. Ahlberg (UK) has restudied sarcopterygian fish material described in the last century from Scotland and has discovered that it included at least two new forms, one a prototetrapod. The latest information on our polydactylous tetrapod relatives was discussed by Jenny Clack (UK) and Michael by Coates (UK). The acquisition of digitated limbs is no longer thought necessary for a terrestrial existence but was more likely the result of heterochrony in limb developmentother people think that maybe the six, seven. or eight finger condition even was due to pathological developmental abnormalities.

A fresh approach at SEVS came from K.S.W. Campbell and R. Barwick (Australia), who gave us a very professionally produced video of their latest expedition to the other classic Frasnian locality at Gogo in
Western Australia. This film made us graphically aware of the vastness and form of the reefal deposits and the stunning threedimensional fish, including new lungfish that they and Dr. John Long (Australia) introduced to us at Miguasha.

A triumph at this meeting was the prominence given to microvertebrate fossils and faunas and their relevance to biostratigraphy, correlation, and paleobiogeography. More than 50 percent of the contributions dealt with these microfossil remains of fish groups (scales, teeth, and spines, for example), which are now the subject of the new IGCP Project 328 on Palaeozoic microvertebrate biochronology and global marinenonmarine correlation. UNESCO and IUGS donated US\$5,000 to the symposium for the travel and living expenses of some of the IGCP Project 328 delegates.

New material was presented at the meeting from the Ordovician, Silurian, Devonian, and Carboniferous of Belgium. Canada, France, China, Morocco, Saudi Arabia. Spain, Netherlands, USA, Germany, USSR, and South America. One macrofossil described by O. Lebedev (Russia) - an osteolepid skull from a locality and horizon from central Kazakhstan, whose details are lost because of a missing label-can be dated to one of two conodont zones in the late Frasnian to early Famennian as a result of the help of a phoebodont tooth found in the acid preparation residue. Phoebodont shark teeth are newly recognized by IGCP members as having great potential as zone fossils in Middle to Late Devonian time. Of particular interest were the insights to be gained from investigating the squamations of whole specimens such as thelodonts (Märss, Ritchie), Cheirolepis (Arratia and Cloutier), and paleoniscoids (D. Esin, Russia; R. Lund, USA; and C. Poplin, France), as well as the equally fascinating study of coprolites, ejecta, and gut contents, in this case from the Escuminac Formation (Jim McAlister, USA). These insights brought to light certain points relevant to our studies of the early vertebrates. First, articulated material does not always answer the questions that are raised by the enormous range of scales seen as microfossils, and second, the microvertebrate fauna from any site will surely complement the evidence known from macrovertebrates. It is no longer enough to consider the macrovertebrates alone: all classic sites should be reexamined for their microvertebrate content during the life of IGCP Project 328. As an example of just one group of fish, almost nothing was known of the history of the "sharks" or chondrichthyans prior to their appearance as macrofossil shark teeth in the Middle Devonian. In the last decade and at this meeting, microvertebrate workers have brought to light shark scales from the earliest Silurian, which extends the history of the group by nearly 100 million years. This raises the question of what actually constitutes a "shark": can it be one if it does not have any teeth?

As is usual at a SEVS, any spare time was spent pouring over the fossil specimens of the host institution and those brought by the participants. Displays and workshops were held throughout the 2 weeks, even on the long bus journeys between field localities! Microvertebrate workshops, which were contributions to IGCP Project 328, were conducted on Silurian thelodont morphology and biostratigraphy (led by Märss, Ritchie, Talimaa, Turner, Wilson, and Vergoossen) and on Devonian to Carboniferous sharks (led by A. Blieck. France; C. Derycke, France; A. Ivanov, Russia; O. Hampe. Germany; Schultze; and R-H. Wang. Germany). These workshops were aided greatly by the park's binocular microscope and television screen attachment.

\section{IGCP Project 328}

The first formal meeting of IGCP Project 328 took place on the evening of June 11 and was chaired by Turner, Blieck, Märss, and N-Z. Wang (China) (four of the six coproposers). Sue Turner and Gavin C. Young (Bureau of Mineral Resources, Geology and Geophysics, Canberra, Australia) were elected by the 28 delegates present as project leaders for the first $2 \frac{1 / 2}{2}$ years, to be followed by the European team of Alain Blieck and Tiiu Märss. The 5-year project is handled in part by stratigraphic subgroups for each system, but each participant may deal with a national representative or directly with the project leaders, especially through the medium of the group newsletter, Ichthyolith Issues, edited by Turner. Young will lead the subproject on a Palaeozoic fish data base, which will contribute to the main task of correlation.

Meetings planned include a Silurian workshop to be run by Märss at Tallinn. Estonia, in 1994: Lebedev will organize a Devonian to Carboniferous workshop in Moscow, Russia, in 1992; and Turner and Young hope to hold Australian workshops at Perth and Sydney in 1992. Field workshops proposed include an expedition to the Falkland Islands, where Devonian fish are known to occur, and to the site of well-preserved basal Wenlockian articulated agnathans on northern Cornwallis Island, Canada, discovered and worked on by Dr. Ray Thorsteinsson of the Institute of Sedimentary and Petroleum Geology, Calgary, Canada. Other areas of interest include central Asia and western Gondwana (southern Chile, the limestones of the Maracaibo basin, Venezuela, and the Arturin basin of eastern Venezu- 
ela; another possibility is work in the Amazon basin). The problems to be overcome in these areas are both the logistics of reaching such remote places when the group has minimal financial support and the shortage of active Palaeozoic vertebrate paleontologists, particularly in South America.

A midterm international Palaeozoic microvertebrate meeting is planned to coincide with the celebration of Professor Walter Gross's 90th birthday anniversary. Gross. who died in 1974, was a pioneer in many Palaeozoic microvertebrate studies. Discussions are underway to hold this in Berlin, Germany, in August 1993.

\section{Fieldwork}

Symposium field trips took place on June 12. 14-16. and 18-21 (details in Vezina and Cloutier. 1991). About 50 vertebrate paleontologists descended with glee onto the Miguasha shoreline, with several journalists in hot pursuit, in order to collect examples of all aspects of fauna and flora. We were ably supported by the Parc de Miguasha's latest local collector and researcher, Norman Parent. A fine trip followed around the tip of the Gaspé Peninsula, where we collected microvertebrates from Upper Silurian to Middle Devonian formations, and we discovered a rich microvertebrate layer in the Battery Point Formation. The final trip took in some of the classic Carboniferous sites of New Brunswick and Nova Scotia, including the oil shales of the Albert Formation. Joggins foreshore. and Horton Bluff close to the famous tidal bore near Truro (fig. 1).

Disappointing was the dearth of students at this meeting; only four were present: one Chinese student from Germany, two from Canada, and one from France. Albeit a symposium of invited participants, it would have been good to see more young people. especially from the Americas where work on Palaeozoic fossil fish now has few devotees. The costs were high, but possibly it is time for the early vertebrate symposium organizers to offer a monetary incentive in the form of a student prize for the best presentation, be it paper or poster.

\section{Acknowledgments}

For financial assistance toward travel and living expenses, I thank the Joseph Burr
Tyrrell Fund of the Geological Society of London; the Canadian IGCP Committee; the Australian IGCP Committee; the Institute of Sedimentary and Petroleum Geology, Calgary, Canada; and the Department of Zoology, University of Edmonton, Canada. In general. my work is funded by a grant from the Australian Research Council.

\section{References}

Vézina, D., and Arsenault, M., 1991, International Symposium, Studies of Early Vertebrates, 7th, Parc de Miguasha, Nouvelle, Québec, Canada, 1991, Abstracts: Parc de Miguasha, Québec, Ministère du Loisir, de la Chasse et de la Pr̂che, $51 \mathrm{p}$.

Vézina, D., and Cloutier, R., 1991, International Symposium, Studies of Early Vertebrates, 7th, Parc de Miguasha, Nouvelle, Québec, Canada, 1991, Guidebook for field trips: Parc de Miguasha, Québec, Ministère du Loisir, de la Chasse et de la Pêeche. 68 p. $\square$

Dr. Susan Turner

Queensland Museum

P.O. Box 300

South Brisbane, Queensland 4101, Australia 


\section{IGCP Project 283: Geodynamic evolution and main sutures of the paleo-Asian ocean}

\section{Shenyang, China, 17-23 September 1991}

In September 1991, International Geological Correlation Programme (IGCP) Project 283 (Evolution of the Paleo-Asian Ocean) convened its second meeting in Shenyang, China. Earth scientists from China, Mongolia, USSR, Japan, USA, and Hungary attended a $2 \frac{1}{2} 2$-day symposium where 42 scientific papers covered a rich variety of topics and resulted in the development of new ideas on the continental growth of Asia. Two separate short field trips climaxed a successful meeting. The first excursion was in southeastern Liaoning Province south of Benxi city in the old lands of the Qianshan Mountains east of Shenyang. Here we observed the northern part of the Early Proterozoic Liaodong rift and the Archean Anshan Group, which contains granite gneiss recently determined by using Australian National University's sensitive high-resolution ion microprobe (SHRIMP) to be $3.8 \mathrm{Ga}$ in age. Cretaceous A-type granites intrude all of these older rocks and may represent a period of extension. The second excursion took place along the northern margin of the Sino-Korean plate and the southern margin of the inner Mongolian-Xingan fold belt within the southern part of the Jilin Hada mountains north of Shenyang. Tectoni- cally this area involves several domains from south to north: (1) the Sino-Korean Platform (pre-Late Proterozoic); (2) the Qinghezen mafic complex, which may be an ophiolite or intrusion (850-550 Ma); and (3) a Paleozoic calc-alkaline intrusive complex consisting of Caledonian to Hercynian granites that may represent a Paleozoic arc. These Paleozoic granites are associated with shallowwater marine sediments that are considered by some Chinese geologists to represent backarc sedimentation. Considerable discussion is taking place as to the location of the suture between the Sino-Korean and Siberian plates.

Important new relationships have been found between granitic intrusions and the final consolidation of Asia, in which A-type granites developed abundantly in the final compressional stages of orogeny rather than developing by extension during continental breakup. Specific petrological papers in areas within China, Mongolia, and USSR demonstrated that Phanerozoic plate tectonic processes are found commonly in Late Proterozoic rocks, which provides new insight into the early continental growth of Asia.

Geophysical studies entailing deep seismic profiles in the USSR and China provide new data on crustal thickness and the tectonic history of late Paleozoic accretion. Geologic interpretation of these seismic profiles supports the idea of diachronous "hard" and "soft" collisions along the same suture zone. The "hard" collision zones represent frontal continent-continent collision that sometimes produced large-scale syntaxis where ultra-high-pressure metamorphic (UHPM) rocks are exposed as part of the final doubling-up of crustal thicknesses. The "soft" collisions along the same suture of frontal collision are characterized by passive movements such as strike-slip motion or rotation, where plates do not actually collide but tend to orient their boundaries within tectonic voids or pressure shadows, much as minerals do in schistose rocks.

Reports on the sedimentary basins of Junggar and Tarim in western China reveal that nearly a continuous record of tectonic activity can be seen from the late Paleozoic up to the present in these stratigraphic "tape recordings" and that these records faithfully detail the "hard" and "soft" nature of the evolving major sutures. Studies of the conti. nental margin of eastern Asia show that it was controlled by an earlier "hard" collision of the Sino-Korean and Yangtze-Cathaysian

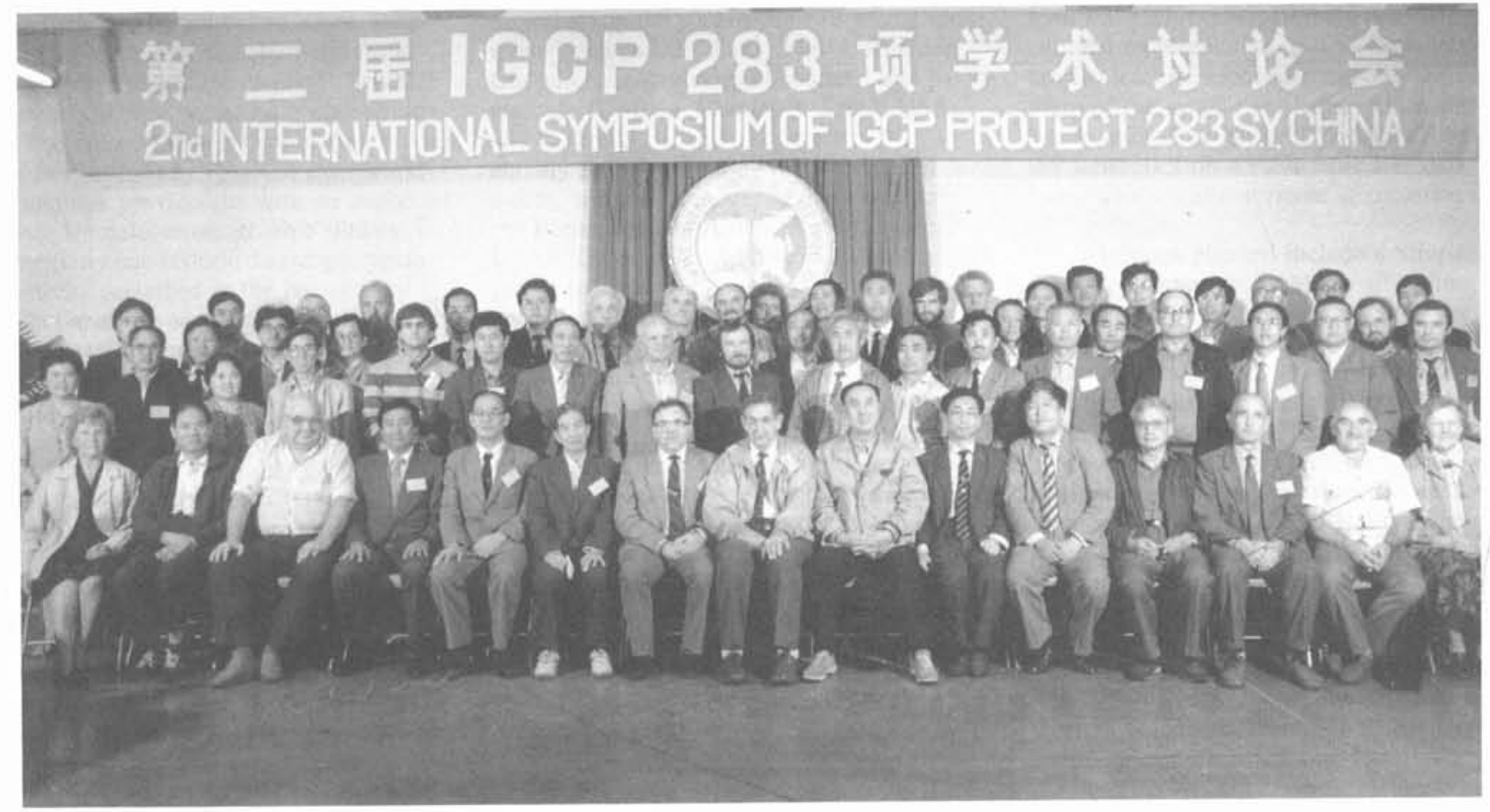


cratons, where a "soft" transform system developed before the Late Jurassic but now is replaced by an active continental margin facing the Pacific Ocean plate.

Some of the younger Soviet scientists have developed a model showing two-layer mantle convection that can explain fluctuations in the lower mantle flow, which may strongly control the development of plumes. An east-west seismic profile resulting from seismic tomography across Lake Baikal produced the pattern of a very complicated structure, but obviously a plume is not responsible for the anomalous heat flow and extension associated with the Baikal rift.

The ultimate goal of IGCP Project 283 is to produce multinational geodynamic maps, as shown in our article in Episodes in 1990 (v. 13, no. 3, p. 184-185). An important step was taken at this meeting regarding the base map. The map will consist of the 1:2,000,000-scale operational navigational charts (ONC) that are available from the U.S. Government. Such maps will be available soon on a CD-ROM disc so that, once the geology is digitized on this base, it will be possible to use various scales and projections. Map compilers have been selected from each country (USSR, Mongolia, China, Korea, and Japan), and their maps will be digitized onto the $1: 2,000,000 \mathrm{ONC}$ base maps.

The digitizing of these multinational maps will be carried out at Stanford University and the U.S. Geological Survey, Menlo Park, California, USA. Geologists from the participating countries will come to Stanford for training as they enter their compilations on the $1: 2,000,000$ ONC maps. These maps will encompass ideas related to terrane maps, but they will show the actual distribution of magmatic, sedimentary, and metamorphic rock assemblages that are indicative of plate boundaries. These rock assemblages will be classified as (1) divergent, (2) convergent, and (3) intraplate assemblages. The main suture zones and outlines of terranes will be drawn on the maps, and their boundaries may be strike-slip faults (transform) or thrust faults.

This year, our meeting will be held in Kyoto, Japan, as part of the International Geological Congress. We will be sponsoring a meeting in the "Structural Geology and Tectonics" session: Symposium II-6-13, "Reconstruction of the Paleo-Asian Ocean," convened by R.G. Coleman (USA), N.L. Dobretsov (USSR), and Xiao Xuchang (China). We hope to have an informal field trip following the symposium. $\square$

\section{Robert G. Coleman}

Geology Department

Stanford University

Stanford, California 94305, USA
Xiao Xuchang

Geologic Institute

Chinese Academy of Geological Sciences

Baiwanzhuang Road

Beijing 100037, China

\section{N.L. Dobretsoy}

Institute of Geology \& Geophysics

Siberian Branch, USSR Academy of Sciences

Novosibirsk 630090, USSR-

\section{ESSENTIAL EARTH SCIENCE FROM CAMBRIDGE}

\section{Saltmarshes}

Morphodynamics, Conservation and Engineering Significance

Edited by J.R.L. Allen

and $K$. Pye

$1992192 \mathrm{pp}$.

41841-0 Hardcover $\$ 49.95$

\section{Morphometric Tools} for Landmark Data

Geometry and Biology

Fred L. Bookstein

$1992452 \mathrm{pp}$.

38385-4 Hardcover $\$ 89.95$

\section{Climate Change}

Science, Impacts and Policy

Edited by Jill Jäger

and H.L. Ferguson

$1992591 \mathrm{pp}$.

41631-0 Hardcover $\$ 95.00$

42630-8 Paper \$44.95

\section{Fractals and Chaos in Geology and Geophysics} Donald L. Turcotte $1992 \quad 231 \mathrm{pp}$. 41270-6 Hardcover $\$ 54.95$
The Ecology of Recently-Deglaciated Terrain

A Geoecological Approach to Glacier Forelands John A. Matthews Cambridge Studies in Ecology $1992403 \mathrm{pp}$.

36109-5 Hardcover $\$ 120.00$

Biomechanics in
Evolution
Edited by J.M.V. Rayner
and $R . J$. Wootton
Society for Experimental Biology
Seminar Series 36
$\begin{array}{ll}1992 \quad 289 \mathrm{pp} . \\ 34421-2 \quad \text { Hardcover } \$ 69.95\end{array}$

The BIRPS Atlas Deep Seismic Reflection Profiles around the British Isles Edited by Simon L. Klemperer and Richard Hobbs $1992128 \mathrm{pp}$. 41828-3 Hardcover $\$ 150.00$

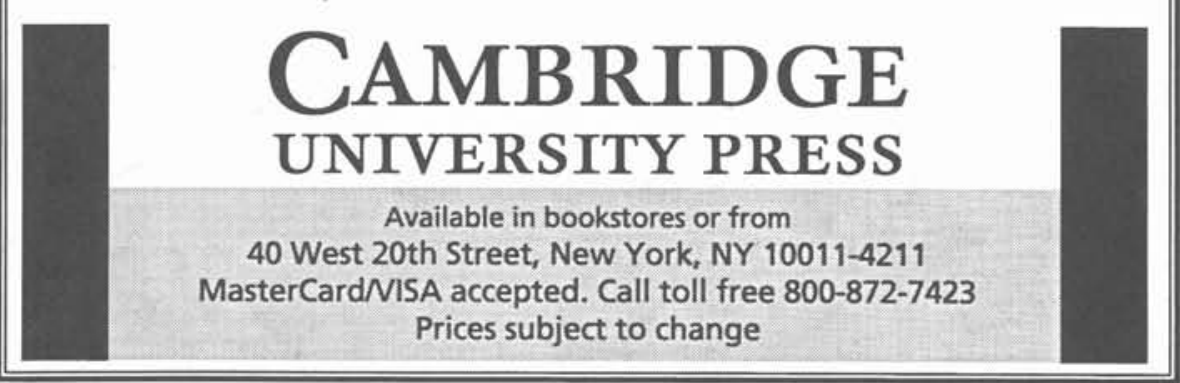




\section{Symposium on Mesozoic to Cenozoic development of eastern Asia and IGCP Project 245 workshop}

\author{
Fukuoka, Japan, 25 August-1 September 1991
}

The eastern margin of the Asian continent provides a critical boundary between the Eurasian and Pacific plates, and the tectonic, sedimentological, and paleontological development of this area during the late Mesozoic and early Cenozoic gives an important understanding of its current geologic fabric. The nature of the many sedimentary basins and their considerable economic significance for the surrounding countries together reveal a geologic history that rarely has been the focus of investigation by most of the nations in the region.

An international symposium was convened in August at Kyushu University, Fukuoka, Japan, in order to address the Mesozoic to Cenozoic development of eastern Asia, which includes the Indian subcontinent, People's Republic of China (PRC), Japan, Taiwan, South Korea, and Russian Far East. This symposium was joined by International Geological Correlation Programme (IGCP) Project 245 (Nonmarine Cretaceous Correlations), which enhanced the focus on nonmarine Cretaceous sedimentology, stratigraphy, and paleontology. The symposium became, therefore, a forum for tectonic geologists, sedimentologists, and biostratigraphers, a mixture that proved unusually fruitful for this region.

Attending were 112 scientists from 12 nations, and 47 papers were presented. Two 1-day postsymposium field trips were orga- nized in order to provide a brief overview of nonmarine Cretaceous and marine-nonmarine Oligocene rocks of southern Japan. Both trips were taken by 27 participants in fine weather, which permitted the travelers to observe sedimentological features of the nonmarine Cretaceous rocks of northern Kyushu and the Oligocene deposits of southwestern Honshu. The deep-lacustrine turbidites of the Lower Cretaceous Kanmon Group were of particular interest. A 5-day field trip to study the Cretaceous nonmarine and paralic strata of western (Tetori) and central (Sanchu) Honshu was attended by 24 participants. Despite a slight rain from a small typhoon, the field trips were extremely informative and congenial. An invaluable 115-page guidebook was compiled for the latter field trip, and it is a definitive account in English of the nonmarine Cretaceous deposits of central Japan.

Two keynote speakers, K.J. Hsü (Switzerland) and D.J. Nichols (USA), spoke on the tectonic structure of southern PRC and on the importance of palynostratigraphy in elucidating tectonic problems, respectively. Hsü's "westernized" approach to Chinese tectonic problems provided a new interpretation of the pre-Cretaceous eastern Asian margin, which he regards as being of Tethyan character and not part of the characteristic circum-Pacific convergence. A later paper given by $\mathrm{E}$. Chang (USA) encouraged a dif- ferent view indicating that pre-Cretaceous convergence had occurred and that the north and south China blocks already had collided in the Paleozoic. The ensuing discussion validated the value of the symposium and the need for a great deal more fundamental research on the structural and basement geology of the region.

A number of papers were given on the tectonic history (S.S. Chun and S.K. Chough, South Korea), sedimentology and stratigraphy (J.D. Son, Y.I. Lee, J.J. Hong, C.W. Rhee, and K.H. Chang, South Korea), and paleontology (S.Y. Yang, South Korea) of the South Korean nonmarine Cretaceous Gyeongsang basin. This basin is related intimately to eastern Chinese and Japanese Cretaceous sequences, and therefore, it provides a crucial linkage for our understanding the Cretaceous development in the region. Interestingly, South Korea is one of the world's great dinosaur track localities, as impressively shown by M.G. Lockley (USA) and coworkers.

J.A. Kalinin (Russia) and M. Matsukawa (Japan) presented a significant paper correlating the Jurassic and Cretaceous strata between Japan and Sikhote-Alin (Russian Far East), wherein they recognized Tethyan and Boreal ammonite faunas across the Jurassic-Cretaceous boundary. This region could well solve a number of hitherto major difficulties in defining this elusive boundary,

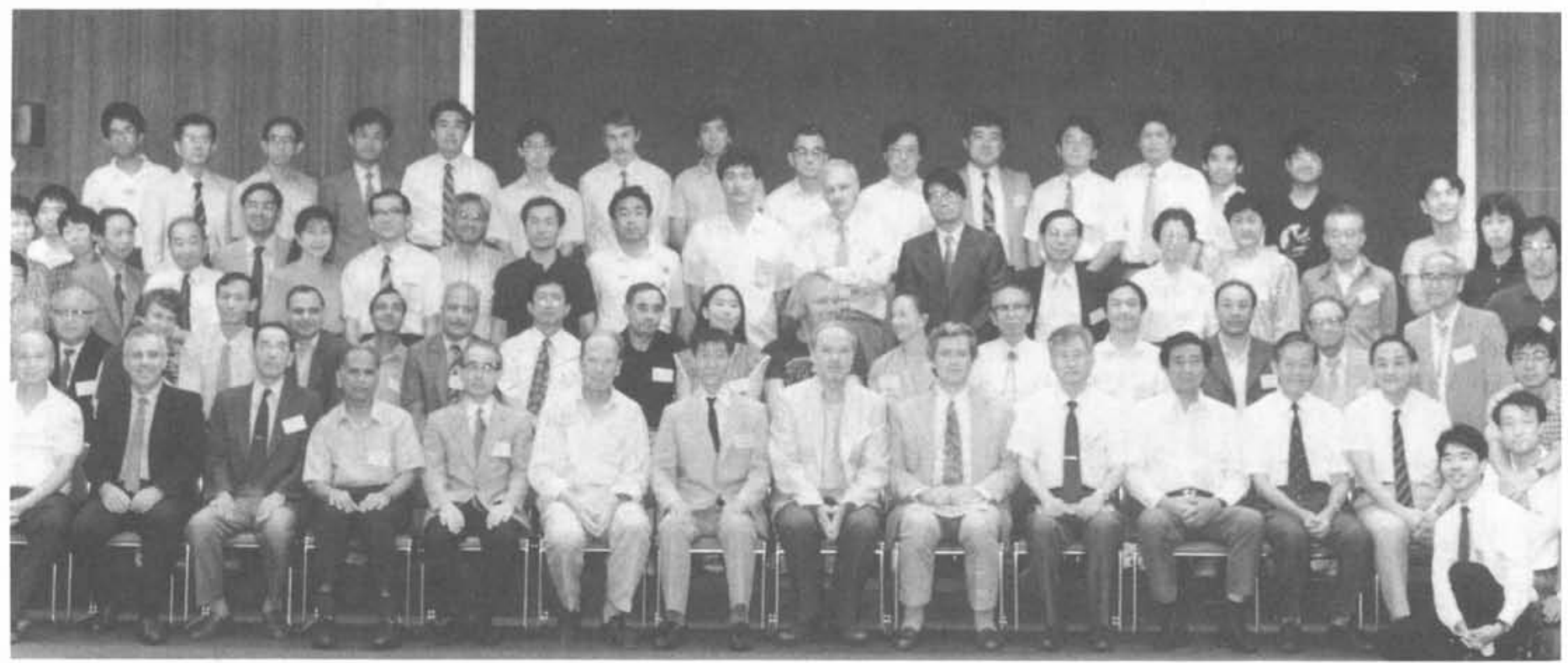


notably the problem of correlating critical Tethyan and Boreal fossils in an effort to accommodate an international standard definition. N.I. Blokhina (Russia) and coworkers provided useful paleobotanical data on the Cretaceous-Paleogene boundary in the Lesser Kuril Islands off the eastern coast of Asia, but they reported no catastrophic change nor any iridium layer.

As expected, numerous papers covered all aspects of the Cretaceous of Japan. $\mathrm{H}$. Okada (Japan) provided an important overview of the Japanese Cretaceous and Paleogene sedimentary basins. He stressed that sedimentary basins in southwestern Japan are characterized by half-grabens, a commonly occurring tectonic feature of sedimentary basins along the Asian continental margin.

Three papers dealt with the early Cenozoic basins of Taiwan and Taiwan Strait and their economic potential. The papers clarified the tectonic development of the Paleogene basins in relation to rifting tectonism on the Asian continental margin.

Last-minute visa problems prevented many Chinese participants from attending the conference, but all their abstracts were published. Chen Pei-ji (PRC) stepped in to provide an overview of the nonmarine Cretaceous stratigraphy of eastern China and how it can be used to explain some structural features of the region, notably the extent of the Tan-Lu fault system. Biostratigraphic evidence indicates left-lateral displacement of approximately $750 \mathrm{~km}$ on the fault.

Although strictly beyond the geographic confines of the symposium, several welcome papers were presented concerning the late Mesozoic history of the Indian subcontinent. C.C. Bhattacharjee (India) provided a useful analysis of the Late Cretaceous-Tertiary Indo-Burman basin where the sedimentology and facies architecture reflect the complex tectonic evolution of this boundary region between the Indian and Burmese plates. S.K. Tandon and A. Sood (India) reviewed the paleoenvironments and fossils from the Inter- and Infra-Trappean beds of central India, as well as how they relate to the Cretaceous-Tertiary extinction in that area. Principal representatives of IGCP Project 245 met to discuss a suggestion that the project be reconstituted in eastern Asia. We decided unanimously that a new proposal should be submitted to IGCP for the much needed, continued study of the Cretaceous rocks of southern and eastern Asia, together with the express hope that the IndoChinese countries and North Korea might participate. We also discussed and approved a recommendation to study the theme of the biological and physical changes during the Cretaceous, and this will form the core of the proposal for a new project. A summary of these discussions was announced during the closing session and received the general enthusiasm of those at the symposium.

The symposium was held in honor of the 77th birthday of Professor T. Matsumoto, the father of Cretaceous geological research in Japan. His active participation throughout the meeting was warmly appreciated, in particular the contribution of his updated biostratigraphic zonation for the Cretaceous System in Japan.

\section{Niall J. Mateer}

University of California

300 Lakeside Drive, 18th floor

Oakland, California 94612-3550, USA

\section{Hakuyu Okada}

Department of Earth and Planetary Sciences

Kyushu University 33

Fukuoka 812, Japan

Masaki Matsukawa

Laboratory of Palaeontology

Nishi Tokvo University

Uenohara-machi

Kitatsuru-gun

Yamanashi 409-01, Japan 


\title{
IGCP Project 249: Andean Magmatism and Its Tectonic Setting
}

\author{
San Juan, Argentina, 17-24 September 1990
}

A 2-day symposium of IGCP Project 249 was held during the XI Argentine Geological Congress in San Juan on September 17-21, 1990. Twenty-three papers were presented, and about 70 scientists from 5 countries attended. A postsymposium excursion, with emphasis on Gondwanic and Andean magmatism, was guided by Dr. Eduardo $\mathbf{J}$. Llambias to the Precordillera and Cordillera Frontal on September 22-24 (see fig. 1).

The Precordillera of San Juan Province is characterized by thick platform carbonates of Early Cambrian to Middle Devonian age with a sedimentary cover of continental Tertiary deposits and is transected by late Tertiary thrust faults. The Precordillera is consid- ered to be a displaced terrain amalgamated to Gondwana at the end of the Ordovician.

At the western edge of the Precordil-

lera, Ordovician mafic and ultramafic rocks have been interpreted as the suture line of the Chilenia terrain that collided with Gondwana during the Devonian. In the Cordillera Frontal, forming the eastern part of Chilenia, postcollisional sedimentary basins were formed in Carboniferous to Early Permian time and extend eastward into the continental environment of the Paganzo sequence in the Precordillera. The sediments in the Cordillera Frontal were intensely deformed during Early Permian time (San Rafel orogenic phase). Pretectonic magmatism began with

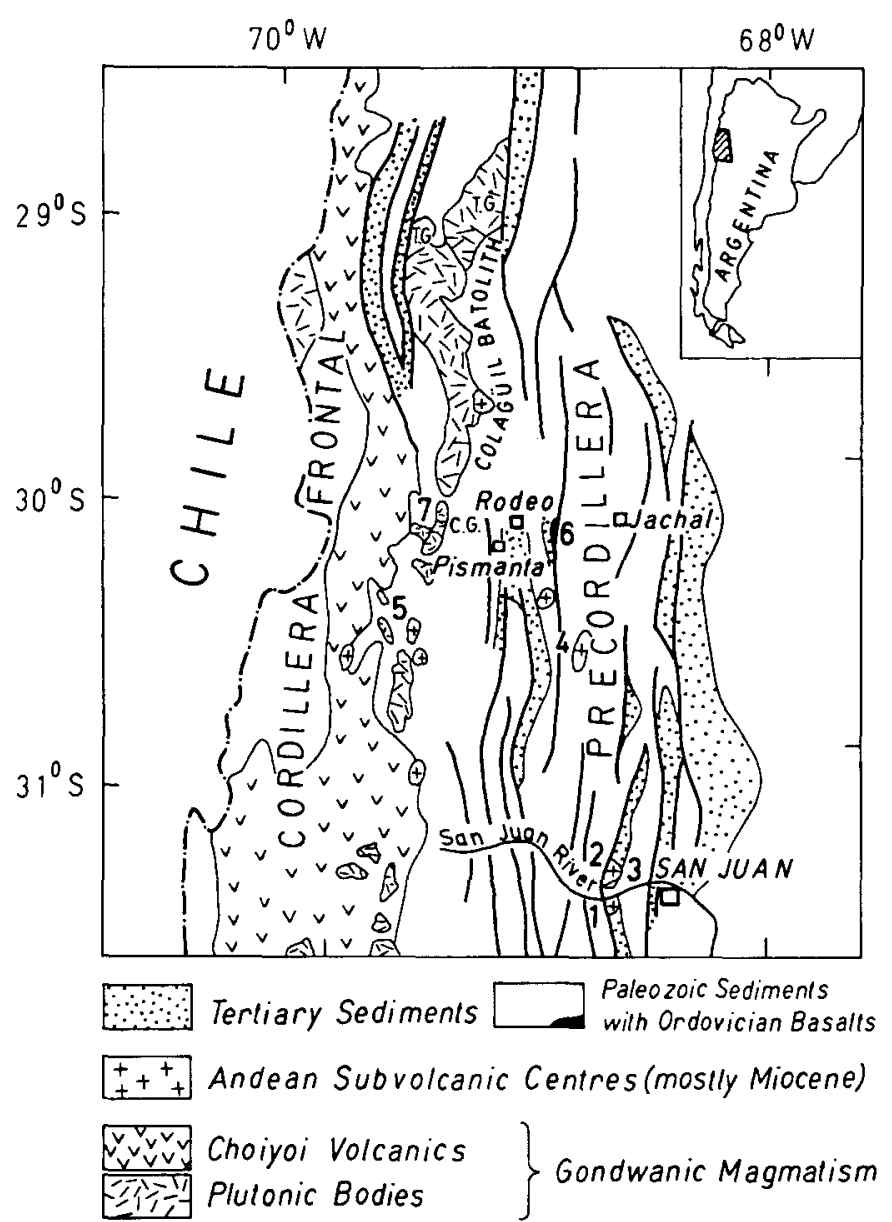

Figure 1.-Geological sketch map of the field trip area (numbers and abbreviations are explained in the text). intrusion of the Tabaquito granodiorite (T.G.) in an area of about $2,600 \mathrm{~km}^{2}$ and formed the oldest part of the complex Permian-Carboniferous Colanguil Batholith. Simultaneously with the Permian posttectonic intrusions, a volcanic plateau was formed by the ignimbritic Choiyoi volcanics. After the Gondwanic events, andesitic to dacitic subvolcanic domes intruded the sediments of the Cordillera Frontal and the Precordillera during the Miocene and indicate a steeper dipping Benioff Zone than in recent times.

On the morning of September 22, 10 geologists (fig. 2) in two camionetas and an Unimog departed San Juan into the Precordillera. At the first two stops, the hornblende dacite of the Cerro Blanco de Zonda laccolith (1), composed of different endogene dome units and containing marked fluidal textures and inclusions of Tertiary rocks, were studied. A sample of dacite from this dome has the lowest IR of all magmatic rocks investigated by Suzan Kay, a fact that was discussed but, as yet, is unsatisfactorily explained and interpreted. Enroute to the Tertiary complex of the Cerro de los Baños, outcrops of ripple-marked graywackes and sandstones and plant-fossil-bearing siltstones and shales, all part of the Devonian Punta Negra Formation, were seen at the northern end of Punta Negra Dam on the San Juan River.

Silurian sedimentary rocks underlie the Cerro de los Baños subvolcanic body (2). The dacite contains not only inclusions of Tertiary sediments but also amphibolites and dacites. Locally, fossil hot springs intensely altered the volcanic rock to kaolinite, which is mined at a few places.

From the marvelous lunch site at the Ullum Dam, we viewed one of the faults of the Precordillera thrust and fold belt by which Cambrian and Ordovician limestones have been pushed onto Tertiary rocks (3). Traveling onward to the north, we crossed several thrust sheets in the valley of Rio Talacasto and made short stops in the rocks associated with the Ordovician/Silurian boundary and in the Lower Devonian. The last outcrop visited on this first day was dacite of the Gualilán volcanic center (4), west of the road from Talacasto to Pismanta. Upon reaching Pismanta, near Rodeo, we were astonished to be accommodated in this semidesert region in a very comfortable hotel with heated bathrooms. 


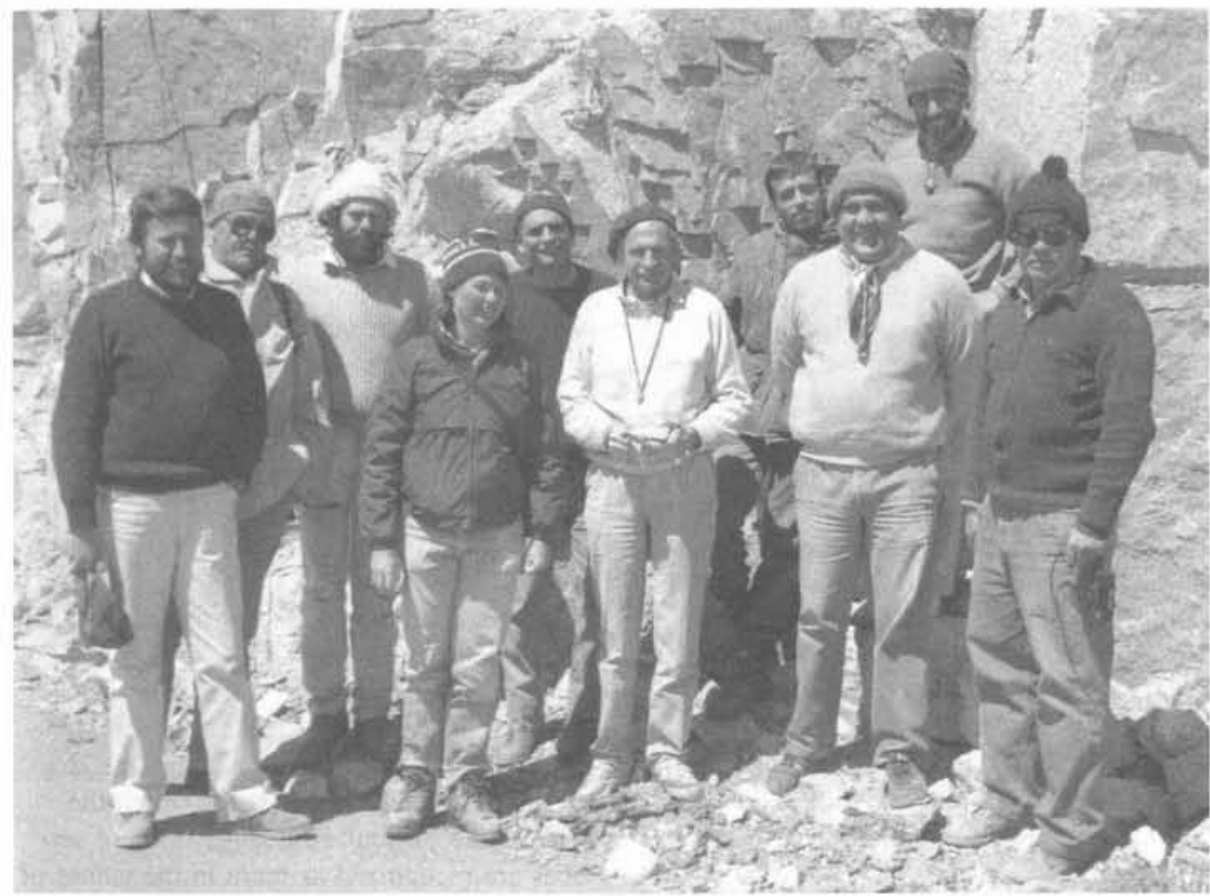

Figure 2. - Field excursion participants include (left to right) Miguel A. Parada, Klaus Schwab, Alberto Saal, Suzan Kay, Carlos W. Rapela, Eduardo J. Llambias, Waldo A. Perez, Carlos Castro, Mario Manzoni, and Carlos A. Cingolani.

The following 2 days were devoted to the study of some of the intrusions forming the Colanguil Batholith in the Frontal Cordillera. In viewing the snow-covered mountain range, none of the sedimentary cover, including the Agua Negra Formation (upper Carboniferous-Lower Permian), the different intrusive bodies, nor the Choiyoi volcanics on top could be distinguished. Certain specimens of the ignimbritic types of the Permian Choiyoi volcanics are very similar to those in the Tertiary. On September 23, we en- tered the Cordillera on the road to the stillclosed Agua Negra Pass, closely inspecting the plant-bearing, deformed sediments of the Agua Negra Formation, cut by rhyolithic dikes, and the contacts of the Lower Permian granodiorite, which have irregular dikes extending into the sedimentary rocks (5). Even though we all rode on the Unimog, we could not reach the Choiyoi volcanics because of the deep snow. We returned to Pismanta earlier than scheduled and so had time to visit some additional outcrops of the Ordovician pillow and columnar basalts that form part of the suture line between the Precordillera and the Cordillera Frontal to the east toward Rodeo (6). The chemical composition of these basaltic rocks in samples from different outcrops is very uniform and directly correlates with the chemistry of the basalts of the recent Reykjanes Ridge. The basalts crop out spectacularly on slopes containing detritus from Tertiary conglomerates. After an ample dinner, we expanded our energy in a ping pong competition; Suzan and Carlos were the winning team.

On the morning of September 24, we examined the Conconta granite (C.G.) in the Conconta and Romo Quebradas (ravines) (7); discussions centered on whether the Cordillera Frontal had already been amalgamated during the plutonic activity. The Conconta granite is cut by rhyolithic dikes that are one to several meters thick and have distinctive contacts on which granitic slices have been displaced. It was quite obvious that these dikes, which have up to 30 percent phenocrysts of quartz and feldspar, did not read the textbook chapter about viscosity of siliceous melts. The mode of intrusion and the temperature of the overheated rhyolithic melts were discussed intensively. In the author's opinion, these rhyolithic dikes in the Conconta granite were the most exciting outcrops of this excellent field trip, on which we saw and learned an appreciable amount about magmatism in the Precordillera and Cordillera Frontal. Many thanks to Eduardo Llambias and the coordinators of IGCP Project 249, Carlos Rapela and Miguel Parada, and also to all participants on the excursion for the fruitful discussions in the field. We traveled back to San Juan during the afternoon of September 24.

\section{K. Schwab}

Germany 


\title{
Australian National Conference on Management of Geoscience Information and Data
}

\author{
Adelaide, South Australia, 22-25 July 1991
}

The importance of geoscience information in Australia was highlighted when some 200 geoscientists, geoscience information specialists, and librarians gathered in Adelaide, South Australia, for a series of workshops and a national conference on geoscience information and data. Five key issues were considered: data standards, the archiving and availability of raw data, the application of geographic information systems, the pricing of government data, and the future of the Australian Earth Sciences Information System.

The development and applications of standards in managing geoscience data were the themes of many of the 30 talks and 16 poster papers given at the conference. The speakers emphasized that data standards are essential if data sets are to be integrated effectively. Data structures have to be independent of the computer systems in which they are used because changes have been made rapidly in those systems. A.P. Belperio (South Australia Department of Mines \& Energy) stressed that the economic life span of computing hardware is about 2-5 years, whereas that of software is $5-10$ years. That standards have a better chance of being used when they are formulated by users and subject specialists, rather than when prescribed by supervisors, was an observation aptly pointed out during the open forum session.

K.F. Mitchell (Stockdale Prospecting Pty Ltd) suggested that the history of the changes that have been made to data sets should be recorded so users can make sound judgments on data quality. Also, users of a data set should know how it was obtained, its accuracy and completeness, and what processing it has undergone. C. Schmidt (Queensland Department of Resource Industries) spoke about the role of a data administrator in assisting an organization to achieve higher data standards. She said that a data administrator provides a key link between the corporate-information users and the specialist-information providers by coordinating the development and use of standards and by promoting the recognition of the information as a corporate resource. R.J. Ryburn (Bureau of Mineral Resources) made a plea for not stifling initiatives by individuals while awaiting the formulation of standards.

Raw data, as opposed to processed or interpreted data, continue to be an essential input to mineral and petroleum exploration. Industry speakers reminded data providers, principally government agencies, of their obligations in archiving raw data and the importance of ensuring that old data are genuinely duplicated by recent data before the former are destroyed. R. Khaiami (New South Wales Department of Mineral Resources) and S.G. Radke (Bureau of Mineral Resources) described their agencies' evaluations of optical technology for storing large volumes of open-file company reports and data: CD-ROM and WORM, respectively. Both techniques are expected to make information and data more readily available to industry on demand.

One session was devoted to geographic information systems (GIS) and spatial data management. Speakers presented case studies on the use of GIS in geoscience mapping and mineral and petroleum exploration, a review of GIS and remote sensing data availability, and a description of the Australian standard for spatial data transfer. Predictions are that inexpensive desktop GIS facilities will be routinely used by 1995 .

A number of industry speakers raised the issue of cost-recovery policies and pricing mechanisms by government agencies that provide geoscience and resources data. Delegates emphasized that data sets should be priced in a way that encourages their use, particularly use by consultants and the smaller exploration companies. Speakers from government agencies pointed out the real threat that exists to withdraw products and services if the cost of providing them is not offset by some revenue. D.J. Richards (CRA Exploration Pty Ltd) emphasized the fact that the value of information is negligible if it is not available for use.

D.A. Tellis (Australian Mineral Foundation) reviewed the status of the Australian Earth Sciences Information System (AESIS) and looked at future scenarios. AESIS has been operating for 15 years and has collected an estimated 75 percent of the significant Australian geoscience information. Over 40 percent of the 88,000 records cover open-file company exploration reports.

Tellis discussed the problems caused by the duplication of the data bases of New South Wales, South Australia, and Queensland in the online system (GEOPAC) but suggested that software could be used to present a single, common data base to users. He also gave the preliminary results of a user survey that showed strong interest in the continuation of the AESIS hardcopy products and encouraging interest in the potential supply of AESIS and other GEOPAC data bases on CD-ROM. The question of a link between GEOPAC and the National Resource Information Center's data-base directory system was also raised. During the open forum session, conference delegates expressed strong support for the continued operation of AESIS.

D.J Lion (Curtin University) presented the results of a cost-benefit analysis of information services with specific reference to AESIS. Her paper, and the discussion that followed, highlighted the problems caused by studies on such services for which the benefits are difficult to quantify. These services are recognized as more in the nature of "insurance policies" for the future use of the exploration and resources industries.

The conference keynote speakers were E. Cameron (Western Mining Corporation Ltd) and D. Dorn (Queensland Department of Resource Industries). Cameron said that exploration is a form of information retrieval and manipulation, which is applied to the discovery of mineral resources. He stated that Australia is well served in the provision of geoscientific information, but that the services are fragmented and need better coordination. Notwithstanding the great strides in electronically delivered information, he is of the opinion that paper still will be around for quite a while. Dorn spoke about geoscience information as a corporate, state, and national asset. She said that in this information age, the possession of relevant information on which informed decisions can be based has become an important factor in success or failure of both the private sector and, perhaps less recognized, the public sector. As an asset, this information must be managed properly to ensure quick, easy, and comprehensive access. Also, in addressing the handling of information, B. Bruce (WMC Petroleum Pty Ltd) examined an holistic approach to data management and its application to reference data base design.

The conference, held at the Australian Mineral Foundation, was preceded by workshops on GIS, data modeling, and indexing, which were attended by 75 participants. The technical displays attracted 21 exhibitors. This national geoscience information conference was the first held since 1975 and had the largest attendance of any that have been held in Australia. 


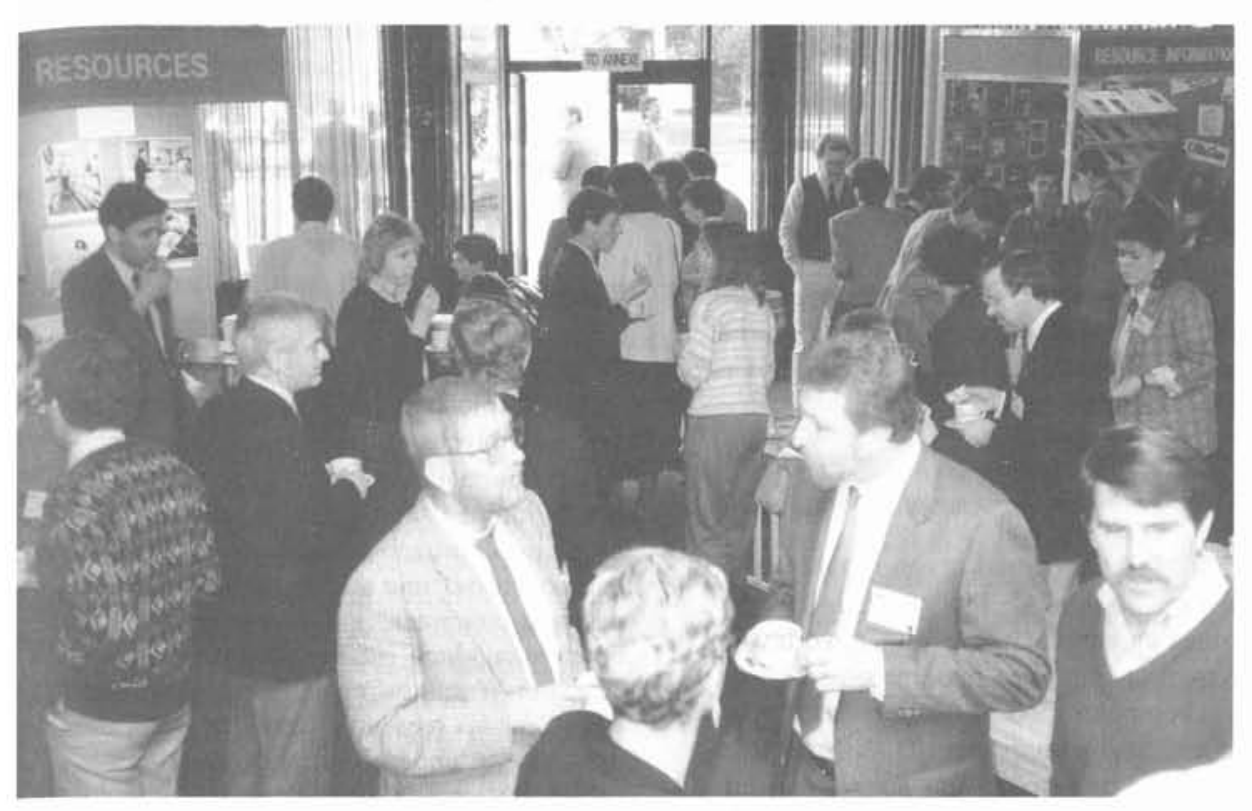

The conference also provided an opportunity for Australia's geoscience information community to bid farewell to Des Tellis, who has now retired from the Australian Mineral Foundation where he has been Information Services Manager since the early 1970s.

Copies of the conference proceedings and limited copies of the workshop notes are available. For details, contact the AMF Bookshop, 63 Conyngham Street, Glenside, SA 5065, Australia (telephone: 618 3790444; telefax: 618 3794634).

\section{E.P. Shelley}

National Resources Information Centre GPO Box 858

Canberra, ACT 2601, Australia 


\section{Hazards-91: Some recent developments in natural hazards research}

\section{Perugia, Italy, 4-9 August 1991}

\section{Introduction}

Hazards-91 is the fourth in a continuing interdisciplinary series of symposiums that began in 1982. The first three were held in Honolulu, USA (1982); Rimouski, Canada (1986); and Ensenada, Mexico (1988). The objectives of this series of symposiums on natural and manmade hazards are to promote the advancement of the hazard sciences, to perceive and explore the aspects that may be similar among some of the various hazards, to review the newest developments in a few selected fields, and to outline new directions for future research

Hazards-91 was held at the Water Resources Research and Documentation Centre (WARREDOC), University for Foreigners, in Perugia, Italy, during August 1991. It was convened by the International Society for the Prevention and Mitigation of Natural Hazards (NHS), which is based in Honolulu, and by the Commission on Natural Marine Hazards of the International Association for the Physical Sciences of the Ocean (IAPSO). The theme of Hazards-91 was "Geophysical Hazards in Developing Countries and Their Environmental Impacts." The conference was attended by about 120 people from some 34 countries, and a total of about 110 papers were presented in 20 sessions.

For the first time, good interaction among social scientists, economists, and planners and managers was achieved for the otherwise somewhat closed group of meteorologists, oceanographers, and seismologists. In the following discussion on the important findings presented at Hazards-91, two assumptions will be made. First, because the journal Episodes deals more with earth sciences rather than atmospheric sciences, we will deemphasize the papers on climatic hazards, except to add that there was considerable interest in the storm surge of April 29, 1991, which killed approximately 140,000 people in Bangladesh. Second, because the theme of Hazards-91 was geophysical hazards (and not manmade hazards such as pollution and oil slicks) in the developing countries, we will not try to summarize the several excellent papers that were presented on hazards in the developed world. One highlight of the meeting was a panel discussion for a full afternoon on the International Decade for Natural Disaster Reduction (IDNDR). Selected papers presented at Hazards-91 and the results from the panel discussion will be published in a special issue of the NHS's Natural Hazards Journal, an issue that will be edited by the authors of this conference report.

\section{Plenary session}

In his talk on coastal ocean hazards at the plenary session, C. Mooers (USA) mentioned an approach to evolve a worldwide system of improved realtime observations and computer models for the coastal ocean. In a second plenary talk, D. Nilson (USA) discussed how specialists planning preimpact hazard mitigation and postimpact disaster preparedness often encounter difficulties in gaining the attention and commitment of their societies and their political and business leaders. These difficulties stem from the low-probability and high-consequence characteristics of most natural hazards.

\section{Earthquake hazards}

H. Strivastava (India) described a method for the quantification of earthquake hazard through an asperity model. E. Abdel-Hafiz and A. Makary (Egypt) discussed reservoirinduced seismicity of the Aswān High Dam. They showed that the largest earthquake occurred 6 years after the water level had stabilized and not during the period of higher water level.

A. Nikolaev (USSR) focused attention on the lessons drawn from the world's devastating earthquakes. He showed that the lessons learned from individual strong earthquakes grow faint a few years after the event and that only a small part of them enriches the experience of society. However, the engineering lessons are much more productive. As a result, many techniques of earthquakeproof building construction have been developed. M. Degg (UK) has studied earthquake hazard in the Middle East and North America, and the resulting new atlas volumes are in preparation under the IDNDR program.

E. Okal (USA) and J. Talandier (French Polynesia) mentioned that the mantle magnitude $\mathrm{M}_{\mathrm{m}}$, which was developed in order to allow the realtime estimation of the seismic moment $\mathrm{M}_{\mathrm{o}}$ of a teleseismic event, bears special interest in relation to tsunami warning.

\section{Tsunami hazards}

A group of papers explored various aspects of tsunami hazards. J. Talandier and others (French Polynesia) have developed an integrated automatic system for a quantitative estimation of tsunami risk. It relies on data from a broadband long-period threecomponent seismic station that is linked to a personal computer, and the system has been operational since 1987 at the Polynesian Tsunami Warning Center. P. LeBlond and J. Lin (Canada) presented formulation for the dynamics of underwater landslides that are a common source of small-scale tsunamis in coastal areas. The presence of a negative leading wave as a possible mechanism for abnormal tsunami amplification was discussed by R. Mazova (USSR).

\section{Flooding hazards}

M. Rafiq (Canada) discussed ways to delineate the impact areas of flooding, particularly the areas flooded by the long-wave runup of seawater during tsunamis and storm surges. He suggested that interpretive deductions of the events can be made by using various biophysical parameters such as electrical conductivity of soils, specific ion concentrations in soils and foliage, vegetation injury symptoms, and survival of salinitysensitive soil microbiota. In the same vein, L. Bravar (Italy) described a new random network model of overland flow. This model can take into account the irregular patterns of waterflow over gullied and (or) ungullied surfaces by considering randomly distributed rill width and water depths. The procedure can be used to model more realistically the overland flow and related soil erosion on natural surfaces. In connection with the floods of August 1988 in Sudan, a study by $S$. Elsheikh and others (Italy) investigated the effects of anomalous rainfall events on sediment transport and subsequent deposition into the water-resource systems of Sudan. They observed that the annual sediment deposition rate was dependent on the length of drought periods between flood events.

F. Camfield (USA) discussed regulatory considerations of shoreline movement. The processes affecting shoreline movement include very long term cycles like eustatic sealevel variations and tectonic changes; relatively long-term cycles such as changes to deltaic lobes and cycles of spit breaching 
and ebb-tidal delta breaching at inlets; random natural events such as hurricanes; and manmade effects such as the removal of dredged material from the system and the impoundment of sediment behind dams on rivers.

\section{Floods and human connection}

T. Cannon (Netherlands) clarified some of the less obvious human connections between natural hazards and disastrous outcomes. He argued that, although hazards are natural, disasters should not be seen as the inevitable outcome of a hazard's impact. His emphasis was on the condition of the people in terms of the extent and types of vulnerability that make it possible for a hazard to become a disaster. He also examined the nonneutral impact of the technical interventions themselves. which are supposed to reduce disaster intensity. K. Krack (Canada), in discussing floods in Bangladesh, also alluded to the negative impact of man's intervention on the magnitude of the flooding problem. Water and sediment are the two components of floods, and most of the causes of flooding are related to changes in the sedimentation patterns.

Further on the subject of floods, J.N. Fonji (Cameroon) discussed the threat of flooding from the accidental failure of a natural dam along the Cameroon volcanic line. The dam, which has 55 million $\mathrm{m}^{3}$ of water stored behind it, is composed of poorly consolidated, pyroclastic surge deposits. Detailed studies show appreciable water seepage through the dam, several stress joints across the spillway on the dam, and a faulted basement. These findings, together with a low safety factor of two given to the structure, suggest the likely failure of the dam by piping and sliding within the next few decades. The flood of water likely will wreak havoc on downstream areas, especially in the vast, fertile, and densely populated plains of Katsina Ala River in Nigeria. This study suggests alternatives for mitigating the flood threats. while taking into account the threat of the explosion of accumulated gas.

By examining the aftermath of the floods of August 1988 in Sudan. K. Andah and F. Siccardi (Italy) analyzed the socioeconomic transformations that had taken place during the long periods of drought that began in the 1960s and the devastating effects of the 1988 floods. In another study of dry and wet conditions, R. Garnett and $M$. Khandekar (Canada) found that an El Niño event generally is followed by low grain yield over southern Asia and normal to high grain yield over the North American prairies.

\section{Conclusion}

The spirit of the symposium perhaps was captured best in a paper by M. Degg (UK). His presentation near the end of the symposium looked at the recent trends and future prospects related to natural hazards. He observed that large disparities in the experience of loss exist, particularly in the contrasts of the fatality/disaster ratios of developed and developing regions. Because the urban populations of developing countries are projected to increase by nearly 200 percent by the year 2025, he concluded that the United Nations' International Decade for Natural Disaster Reduction is a most timely initiative. $\square$

T.S. Murty

Institute of Ocean Sciences

Department of Fisheries and Oceans

P.O. Box 6000

Sidney, British Columbia V8L 4B2, Canada

S. Venkatesh

Atmospheric Environment Service

Environment Canada

4905 Dufferin Street

Downsview, Ontario $3 H$ 5T4, Canada 


\title{
International field workshop: Geotraverse through the Mozambique belt of Tanzania
}

\author{
Dar es Salaam, Tanzania, 23 July-August 61991
}

An international field workshop was held in July and August 1991 in Tanzania. The workshop was sponsored by the United $\mathrm{Na}$ tions Educational, Scientific, and Cultural Organization (UNESCO)-Geology for Development and was organized by the Geology Department of the University of Dar es Salaam and the Geological Society of Africa. The main aim of the field workshop was to bring together researchers who are carrying out geological studies in the Pan-African Mozambique belt of northeastern and eastern Africa in order to share and compare as much data as possible and to serve as a training workshop.

The meeting was attended by 25 geologists from Africa, Australia, and Europe, and they were welcomed by the Dean of the Faculty of Science, University of Dar es Salaam, and by $\mathrm{S}$. Muhongo, Chairman of the Organizing Committee. Geology Department, University of Dar es Salaam. The workshop included 23 oral presentations that were spread over 5 days, as well as 6 days of fieldwork. The oral presentations were organized in such a way that topics relevant to the fieldwork were discussed a day earlier and field traverses were taken every alternate day. In order to make a field traverse along the eastern part of Tanzania, the meeting moved to the towns of Morogoro and Mpwapwa, which were closer to the areas of interest.

The first session featured a keynote speech by S. Muhongo about the Mozambique belt. Presentations followed on the tectonic development of the Pan-African Mozambique belt of northeastern and eastern Africa (S.M. Berhe, Open University, UK) and on the Proterozoic fold belts east of the Tanzanian craton (A. Mruma. University of Dar es Salaam). The keynote lecture by $\mathrm{Mu}$ hongo described the structural and tectonic complexity of the Mozambique belt that results because the belt was affected by multiple orogenies, which have led to problems determining the ages of the orogenic events. Berhe mentioned that the northwest-southeast collision postulated previously for the Mozambique belt is more complicated, as indicated by the presence of northwestsoutheast and north-south stretching lineations. He suggested a two-stage collisional model for the evolution of the Pan-African Mozambique belt. A major contribution to our understanding of the Mozambique belt in Tanzania was suggested by Mruma, who argued that the Proterozoic belts east of the Tanzanian craton should be divided into two major units. Specifically, the units adjoining the craton are classified as Early Proterozoic units, whereas further to the east, the units are described as Late Proterozoic and, hence, are correlative with the Pan-African rocks further to the north. The forum concluded with a session on UNESCO's contribution to the development of earth sciences in Africa. A. Nesci (UNESCO, Kenya) described the change in the priorities of UNESCO in funding future training and (or) research workshops.

The next day a traverse was made from Dar es Salaam to Morogoro, and in this traverse, we observed in a number of quarries the contacts between the Jurassic sediments and the Proterozoic Mozambique belt, as well as the different folding phases of the belt. The next oral presentation focused on the geologic evolution of the Uluguru Mountains and their mineralization. These mountains are known for the widespread presence of granulite gneisses and meta-anorthosites plus the ubiquitous development of pegmatites. Geologists from the Geological Survey of Tanzania (F.L.K. Mbawala, A.P. Msolo, and S.A. Naumanga) described the various minerals, such as mica, gemstones, and rare earths, that are associated with the pegmatites. The meeting concluded with a stimulating discussion on the role of fission-track dating and on the geochronology of the Mozambique belt. This discussion was convened by J.W. Gleadow and A. Foster (LaTrobe University, Australia). They have carried out reconnaissance sampling for the fission-track dating of the rocks of the Mozambique belt from Dar es Salaam to the Dodoma region. The following 2 days were spent studying the structural relationships of the various units in the Uluguru Mountains.

On the sixth day, papers were presented on the regional geology and mineral deposits of the Mozambique belt in Malawi and Burundi. E.E. Chipili and B.W.C. Manda (Geological Survey of Malawi) reviewed the geology and tectonic evolution of Malawi, and E. Njojibani (University of Bujumbura. Burundi) gave us an insight into the relationship of the Mozambique belt in Burundi with other belts such as the Irumide and Kibaran belt of central Africa.

On the eighth day, the field workshop moved to Mpwapwa, and the oral presentations concentrated on the geology of the
Mozambique belt in Kenya and Uganda. C.M. Nyamai and E.M. Mathu (Geology Department, Nairobi University) presented a review of the geology and tectonic history of the Mozambique belt in Kenya. Mathu noted the presence of island-arc rocks in the central part of Kenya, which suggests that the accreted arc terranes of the Nubian Shield may continue south to Kenya. One of the contentious issues was whether the ophiolites that have been reported in Ethiopia and Kenya continue southward into Tanzania and Uganda. The review of the geology and mineralization of the Karasuk area of northeastern Uganda (J.T. Tuhumwire and D.P.M. Hadoto, Geological Survey of Uganda) indicated that rocks exist there that are similar to those described in northwestern Kenya. Although the rock assemblages in Tanzania (Mpwapwa area) and in the Karasuk area are similar, we should await detailed geological and geochemical studies in order to be able to suggest their tectonic settings. Because the Karasuk belt contains economic deposits of chromite and gold, collaborative research efforts should be undertaken by the Uganda and Kenya Geological Surveys and other interested academics. The following day, fieldwork in the Mpwapwa area examined the dismembered mafic-ultramafic rocks and the transition belt between the Tanzanian craton and the Mozambique belt.

The last day of the oral presentations focused on Somalia and Ethiopia. The possible continuation of the Mozambique belt into Somalia and the existence of Archean rocks have been confirmed in the Burr region of southern Somalia. J.L. Lenoir (Tervuren, Belgium) also discussed the age, nature, and origin of the granitoid rocks of Somalia. W. Ghebreab (Institute of Ethiopian Geological Surveys) presented a very stimulating lecture on the tectonic evolution of the Adola belt in southern Ethiopia, which has economic deposits of gold. He also noted that shear zones played a major role in the emplacement of gold mineralization in southern Ethiopia.

On the last day of the field workshop, we held a major discussion on the future of geological research in the Mozambique belt. The fieldwork clearly demonstrated that the geology of northeastern and eastern Africa is comparable and that more interaction among the geoscientists working in the area would greatly benefit everyone involved if similar localities were visited jointly. In addition, if 
the countries of East Africa are to benefit from exploiting their natural resources, a proper understanding of the geology and tectonic history of the area is required. Among the major geological problems highlighted was the lack of reliable geological maps and geochronological data. The relationship of the Pan-African accreted arc terranes and the Mozambique belt, as well as the relationship of these belts to the Irumide and Zambezi belts, is not clear.
The participants agreed on the need of establishing a working group on the Proterozoic fold belts of East Africa. Hence, the working group has been duly named "Working Group on the Mozambique and Related Belts in the Eastern African Continent: Evolution and Mineralization" (MRB). Its current tasks are to publish the proceedings of the meeting and to create working groups in the various East African countries. Each of these working groups will take the role of compiling geological maps and of inventorying the mineral resources in their respective countries. This will lead to joint fieldwork in the border areas of the collaborating countries, and the results will be presented in another field workshop to be held sometime in 1993 in Malawi.

\section{Seife $M$. Berhe}

Department of Earth Sciences

Open University

Milton Keynes, UK

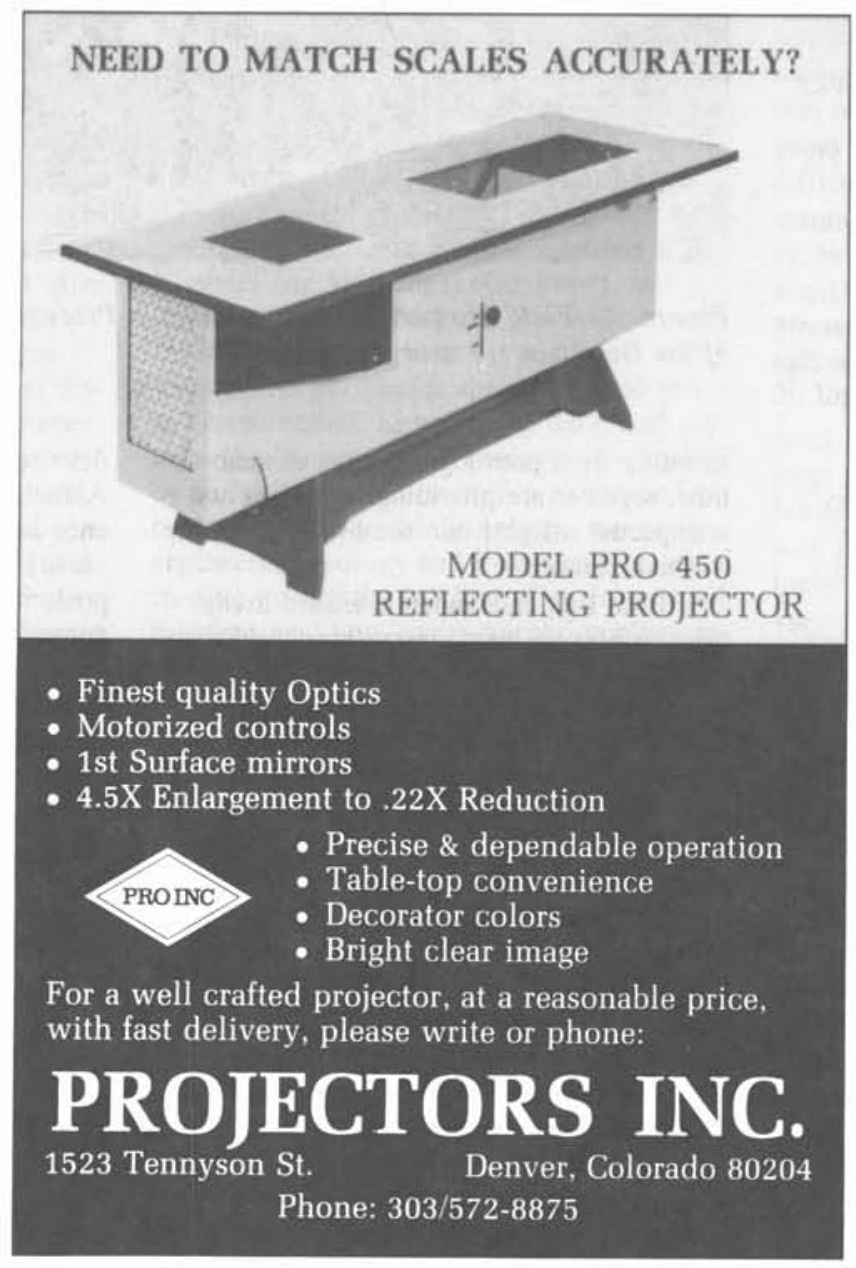




\title{
First International Symposium on the Geodynamic Development of the Arabian Lithosphere
}

\author{
Irbid, Jordan, 24-26 August 1991
}

Supported by the United Nations Educational, Scientific, and Cultural Organization (UNESCO), this symposium was held at Yarmouk University and was attended by 80 earth scientists from many different Arab countries (Egypt, Syria, Sudan, Libya, Tunisia, Iraq, United Arab Emirates, Jordan, and Saudi Arabia), as well as from Germany, England, and the USA. The program concentrated on the following themes: (1) geodynamic development, rift evolution, and lithosphere characteristics; (2) PanAfrican and Arabian-Nubian Shield evolution; (3) sedimentary basins of the Arabian plate; (4) geophysical aspects of the Arabian plate; (5) tectonic and structural studies within the Arabian plate; and (6) hydrology and hydrogeology within sediments.

A total of 45 separate papers were presented. The following keynote speakers opened separate symposiums: R.G. Coleman (USA) spoke on "Geological Evolution of the Red Sea"; R.O. Greiling (Germany), "Early (Pan-African) Structural Development of the Arabian-Nubian Shield"; R.W. Girdler (UK), "The Dead Sea, Red Sea, and Gulf of Aden Margins of the Arabian Plate"; Z. El-Isa (Jordan), "The Jordan-Dead Sea Transform: A Continental Plate Boundary"; S.A. Alsinawi (Iraq), "Crustal Structure Determination in Iraq From Long-Period P-Wave Spectra"; Z. Al-Shaikh (Iraq), "Some Aspects of the Regional Field Over Northern Iraq and Its Geologic Interpretation"; and H. Wachendorf (Germany), "PanAfrican Molasse Evolution in Southwestern Jordan." In addition, two field trips were held. One traveled to the Dead Sea and along the Dead Sea rift zone, and the other went south to the head of the Gulf of 'Aqaba (fig. 1).

In the final session, which was left open for general discussion and comments, we agreed that a need exists for such a conference to be held every 2 years. The growing geophysical data base and new evidence on the nature of the lithosphere, which is

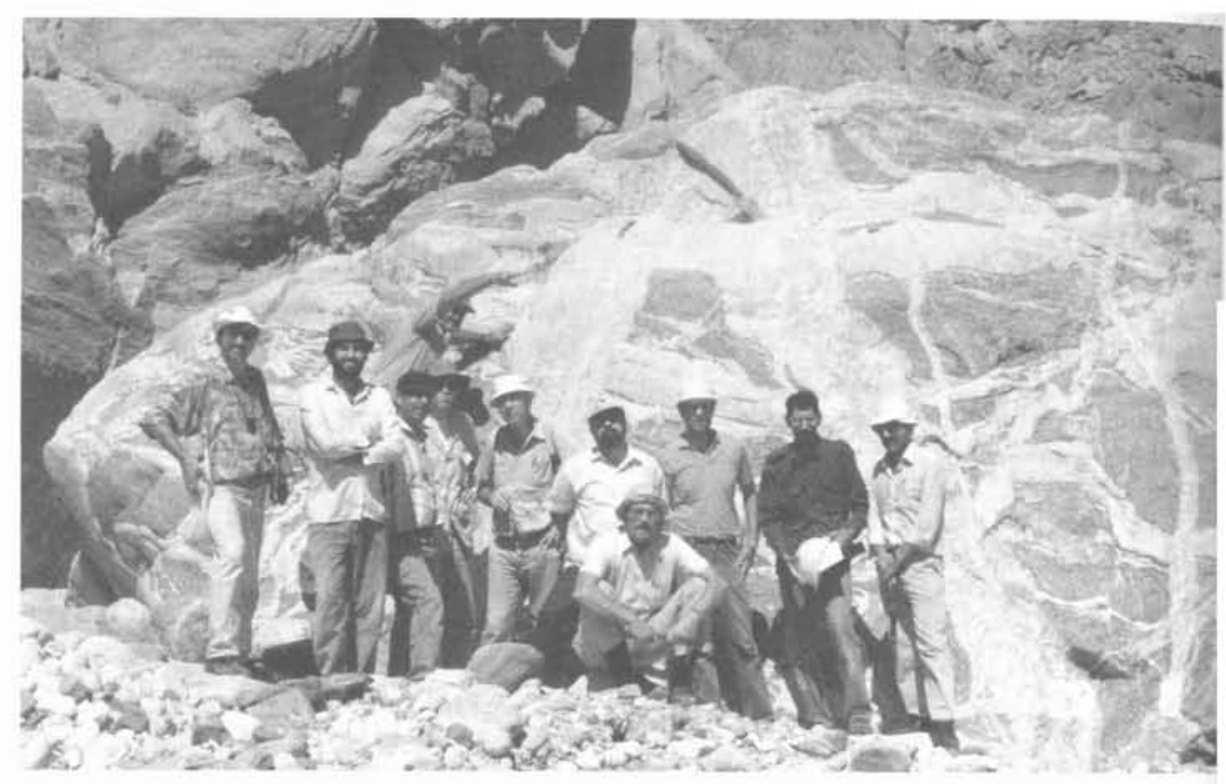

Figure 1.-Field trip participants standing on Precambrian exposures at the southern end of the Dead Sea rift zone.

resulting from petrologic studies of xenoliths, together are providing important and unexpected insights into the evolution of the Arabian plate.

Both Iraq and Sudan extended invitations to host the next symposium. Additional comments brought out the importance of developing further geological and environmental mapping of the Arabian plate. We agreed that members of the symposium should develop an International Geological Correlation Programme (IGCP) project that could involve all the countries interested in the geodynamic development of the Arabian lithosphere. Submission of this proposal will take place in the near future. The formation of an IGCP group would open many new aspects of cooperative work such as, for example, a regional scientific earth science journal that would report new and interesting developments. As a start in this direction, Abhath al-Yarmouk, Journal for Pure Science and Engineering Series, Yarmouk University, will publish 16 papers from the symposium, the papers to be chosen by a special committee.

Readers interested in obtaining the abstract volume of the symposium should send US\$10 to Dr. S. Nasir, Department of Earth and Environmental Sciences, Yarmouk University, Irbid, Jordan. $\square$

\section{Dr. Sobi Nasir}

Department of Earth and Environmental Sciences Yarmouk University

Irbid, Jordan

Professor R.G. Coleman

Department of Geology

Stanford University

Stanford, California 94305, USA 


\section{New waves of geology}

\section{Budapest, Hungary, 22-28 August 1991}

The First International Meeting of Young Geologists was held in Budapest in August 1991. The meeting was conceived by a group of young geologists in Hungary who wanted to initiate a new type of meeting that would provide a forum for students across Europe and beyond and would provide an opportunity to learn the latest ideas on their specialty subjects and, at the same time, broaden their perspective on geology and its applications. Significantly, the promotion of such a meeting came from a country that has been isolated from the personal contacts that all of us in North America and Western Europe take for granted and where, even now, financial limitations make travel abroad difficult, especially for younger scientists.

The organizers' plan was to invite a number of well-known teachers (18 in all) from abroad or from their own country to give a series of 1-hour lectures outlining the latest information on their subjects to all the participants. This 3-day period of plenary lectures was followed by 1 day of field trips that were led by Hungarian geologists, including students, so that they could show their outcrops to others and have critical discussions. After this, 3 days of short courses ran in parallel sessions, each teacher giving a one-half-day or full-day course and each student choosing which course to attend. An important element here was the flexibility that allowed the students to decide during the plenary lectures what to take and even to move from one course to another during the short courses.

Although not every aspect of the geological sciences was covered, the range was broad and included not only the more academic aspects but many applied fields as well, some of which were almost entirely new to certain of the participants.

The main themes were as follows: (1) Sedimentary geology was covered by P. Homewood (France), H.G. Reading (UK), and W. Schlager (Netherlands), who together demonstrated the similarities and differences between clastic depositional systems and carbonate platforms, as well as the relationship between classic sedimentology and the new ideas of seismic and sequence stratigraphy. (2) Tectonics and geophysics were reported by A.W. Bally (USA) and F. Horváth (Hungary), who concentrated on seismic reflection, mountain building, and the great enigmatic basin of Pannonia, within which the conference was located. (3) Petrology and geochemistry were taught by J.-M. Bardintzeff (France) and H. Downes
(UK), who between them showed the relationship of mantle sources, magma chambers and eruptions, and the application of isotopic data to the origin of magmas. (4) Paleontology and stratigraphy were covered by J. Remane (Switzerland) and J. Callomon (UK), and they emphasized the importance of time in geology and biostratigrahy and discussed the methods of defining chronostratigraphic boundaries by boundary stratotypes. (5) Geomathematics and geostatistics were covered by M. Armstrong (France) and N. Gustavsson (Finland), who showed the value of kriging in geology and how statistics can be applied to geochemical data. (6) Agrogeology was discussed by L.P. Gough (USA) and G. Stoops (Belgium), who explained how geological knowledge and techniques are being applied to agriculture, in particular the development of soils, and how, in return, pedological methods can be used to solve geological problems. (7) Engineering geology was covered by P.G. Marinos (Greece) and M. Langer (Germany), and they demonstrated both the growing demand for well-trained engineering geologists and how the subject can be applied to road and rail construction, as well as to dams and tunnels. (8) Environmental geology was detailed by K.A. Czurda (Germany), who showed how many geological disciplines, especially engineering geology and hydrogeology, are moving toward the tackling of environmental problems and how environmental geology is now an individual and expanding subject. (9) Paleokarsts were covered by M. Esteban (UK) in a lively talk that was very instructive. particularly on the subject of giving talks, to both students and teachers in the plenary session on the presentation of science. (10) J. Déak (Hungary) taught how to determine hydrogeological parameters from geological, hydraulic, and isotopic data. Fortunately, the President of the International Union of Geological Sciences, U.G. Cordani, welcomed participants to the meeting. and the Secretary of the International Geological Correlation Programme, E. Dudich, explained how international cooperation works in the earth sciences.

Although Hungarians clearly dominated, the students came from a variety of countries. Some came from close by, especially those from Romania, Slovenia, Poland, and Czechoslovakia, and some were outside their own countries for the first time. A large and very impressive contingent traveled from Finland; a number, from Germany, Spain, and Italy; one each, from Greece and Can- ada; and a group, from China. The Chinese students had traveled by train for 8 days across the Soviet Union at the time of the abortive coup, and sadly, after only 3 days at the meeting, they had to go back. Most of the students were graduate students who already had started their research, but others were undergraduates, such as a large group from Madrid, Spain, and were still open to all the geological disciplines. Thus, the range of knowledge of the classes was varied, and the short courses had to have a sufficiently flexible formula in order for all to benefit.

The students themselves had been encouraged to bring posters, and plenty of time was provided for examining these and discussing them with the presenters. A competition was held, and the teachers formed a panel to pick the best poster. Their task was difficult, and in the end, they decided to commend a number of posters as excellent. However, the prize went to Kaisa-Leena Hutri and Anne Voutilainen from Helsinki, Finland, for their poster on the use of geology in making indoor radon measurements.

The field trips were a welcome midweek break and gave an opportunity to the local geologists to present their rocks and interpretations to an external audience, as well as gave the younger students an opportunity to listen to arguments for and against various interpretations. Two trips went to the nearby Buda Mountains, one to see Eocene tectonic structures and sedimentology, led by László Fodor, Arpád Magyari, and Attila Fogarasi, and the other to examine the hydrology, paleokarst, environmental geology, and engineering geology of the district, led by Annamária Nádor and Ákos Török. Another group traveled to the more distant Vértes and Gerecse Mountains, where participants saw bauxites, platform carbonates, and a deep-sea fan and slope apron system on this trip led by András Galâcz, Janos Haas, Andrea Mindszenty, and Orsolya Sztanó. The excursion ended in a visit to the Tata Geological Nature Conservation area. Here, outcrops have been preserved in a beautiful park that shows with great clarity the Mesozoic history of Hungary in an incredibly condensed Mesozoic sequence. Both time and sedimentology are demonstrated to the general public and to geologists. The geological park is an outstanding example of what can be done by dedicated geologists in order to show our story to children and adults. It is a must for anyone who is visit- 
ing Hungary to see, and it is a model that should be followed in many other countries.

The social side was not neglected. After the first night's icebreaker party, we had a night of Hungarian music and dancing, in which everybody joined. A large "final" party was held on the next to last night, and on the final night, a barbecue set in the wooded hills was organized extempore by the students themselves.

The initiative for the meeting came from young geologists in Hungary themselves, in particular Anna Balog, who had the original idea, and Annamária Nádor, Orsolya Szłanó, Györgyi Juhász, and Ákos Török, with help from János Haas, who carried through the organization. Substantial help was given by the International Associations of Sedimentologists, of Hydrogeologists, and of Mathematical Geology and by the Hungarian Geological Society, Hungarian Geological Institute, Geophysical Exploration Company, Eötvös Loránd Geophysical Institute, Eötvös Loránd University where the conference was located, Nagyalföld Oil and Gas Production Company, Tele-geo Ltd., Budapest Technical University, and Dr. Imre Leskó. Without them, it would not have been possible to bring in so many foreign professors and to keep the fees down to US\$85 for the lectures, short courses, and field trips.
The participants felt that the format of 3 days of introductory plenary lectures, a field trip, and then 3 days of parallel courses was just right. Everybody agreed that a second meeting must be held in 2 years' time, but though several venues were discussed, no firm invitation has been put forward. It is open to any group of young, enthusiastic geologists to formulate plans for a future meeting that will cover, once again, not the whole spectrum of geological sciences, but perhaps six or seven topics just as this meet- ing did. This would bring together again an international group of teachers and young geologists from anywhere in the world to a convenient meeting place. If anyone has such an idea, please contact Orsolya Sztanó, Department of Geology, Eötvös Loránd Uni versity, Múzuem krt. 4/a, Budapest H-1088 Hungary.

\section{Harold G. Reading}

Department of Earth Sciences

Parks Road

Oxford OXI 3PR, UK

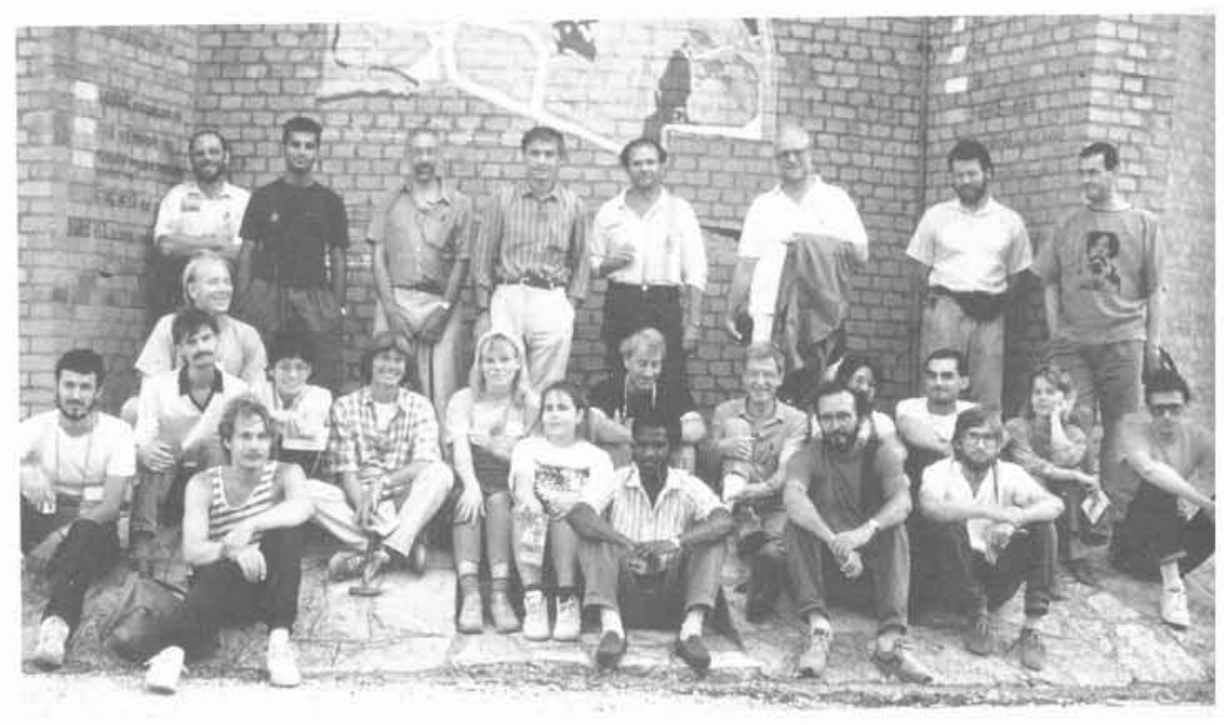

Field trip participants in the Geological Park, Tata. 


\section{Symposium on Central European Alkaline Volcanic Rocks: SCEAVR 1991}

\section{Prague, Czechoslovakia, 24-29 June 1991}

SCEAVR 1991, which was attended by almost 60 professionals from 9 different countries, was, in a sense, a continuation of the International Volcanological Congress held by the International Association of Volcanology and Chemistry of the Earth's Interior (IAVCEI) in 1990 in Mainz. Germany. The last such international scientific conference on volcanic rocks in Czechoslovakia was held in 1965 at the Faculty of Natural Sciences of Charles University in Prague, if we do not count the prematurely terminated International Geological Congress in 1968.

The actual meeting was preceded by a 1-day excursion to the Barrandian area in western Czechoslovakia. where the participants became acquainted with Proterozoic and Paleozoic volcanic rocks, which were of the greatest interest at the Conference on Paleovolcanics in 1965 . Thus, the relationship between these two scientific meetings was emphasized.

The 2 days of lectures and panel discussions took place again at the Faculty of Natural Sciences of Charles University in Prague. The Deacon of the Faculty and the Honorable Chairmen (directors of important geological institutions in Czechoslovakia) attended the opening ceremony, where the speakers summarized contemporary knowledge on the alkaline volcanic rocks of central Europe and, especially, of Czechoslovakia. M. Wilson (Great Britain) stated that "the Neogene primitive basic alkaline magmas in Western and central Europe (rift system including Limage, Brese, Rhine, Ruhr, Leine, and Eger grabens) were erupted through a variably thinned continental lithosphere, which had experienced a complex history of deformation and magmatism during the Hercynian orogeny. To explain the major and trace element and $\mathrm{Sr}-\mathrm{Nd}-\mathrm{Pb}$ isotopic characteristics of these alkaline magmas requires the involvement of both lithospheric and asthenospheric mantle source components. Neogene magmas reflect, in part. the characteristics of the terrane block through which they were erupted."

The subsequent lectures emphasized the material structure of volcanism, as the greatest amount of new data has been obtained on the mineralogy, petrology, and geochemistry of volcanic rocks. All the participants obtained symposium abstracts and excursion guides, which also are available in the geological libraries of the Faculty of Natural Sciences of Charles University and of the
Central Geological Institute and Geofond in Prague. The proceedings of SCEAVR 1991 will be published in the journal Mineralogy and Petrology (formerly TMPM, Tschermaks Mineralogische und Petrographische Mitteilungen) in Austria.

The symposium dealt primarily with the following subjects: (1) the formation and development of alkaline volcanic rocks, including their mineralogy, petrology, and geochemistry; (2) volcanology; (3) melilitic rocks; (4) trachytes and phonolites: (5) lamprophyres: (6) alkaline plutonites; and (7) various other interesting subjects.

Regarding the formation and development of alkaline volcanic rocks, F. Fediuk (Czech and Slovak Federal Republic, CSFR) pointed out that alkaline volcanites are not limited in the Bohemian Massif to Tertiary volcanism but are found also in older (Proterozoic and Paleozoic) volcanic forms. This was illustrated by A. Prrichystal (CSFR) on the example of Devonian volcanism in the Sternberk-Horní Benešov belt in northern Moravia. L. Kopecký, Sr. (CSFR), gave a summary of the four stages of development of Cenozoic alkaline volcanism in the Bohemian Massif and particularly demonstrated the recently recognized alkaline metasomatism in young alkaline volcanic centers (sodium- and potassium-feldspathization). Similar views of the Mesozoic to Quaternary alkaline volcanism of Slovakia were presented in the lectures of D. Hovorka, P. Ivan, and J. Spišiak (CSFR).

A number of the contributions dealt with the geochemistry of volcanic rocks in specific regions. For example. H. Huemer (Austria) described work in the eastern Mecsek Mountains in Hungary; M. Vaněčková and others (CSFR) studied the Tertiary volcanic rocks of the Czech Cretaceous basin; M. Chlupáčová and others (CSFR) described the distribution of thorium. uranium, and potassium in young volcanic rocks of the Bohemian Massif; and J. Bendl, K. Vokurka (CSFR), and B. Sundvoll (Norway) studied the strontium and neodymium isotopic composition of the Cenozoic basaltic volcanic rocks from northern and western Bohemia. On the basis of isotope systematics, the source mantle reservoir of the Bohemian Cenozoic basalts seems to be close to HIMU (isotopically distinct mantle component with high ${ }^{206} \mathrm{~Pb} /{ }^{204} \mathrm{~Pb}$, low ${ }^{87} \mathrm{Sr}{ }^{86} \mathrm{Sr}$, and interme- diate ${ }^{143} \mathrm{Nd} /{ }^{144} \mathrm{Nd}$ ratios) in transition to PUM (primitive upper mantle) or BSE (bulk silicate Earth).

Finally on this subject, V. Morogan (Sweden) and H. Sørensen (Denmark) reported on their studies of acidic and basaltic rocks in net-veined complexes in the Oslo rift.

The results of volcanological research were presented mainly as posters. V. Cajz (CSFR) has found two structurally different stages of volcanism in the České Středohoři Mountains of northwestern Czechoslovakia. The lower stage (most effusive) was subaqueous and produced hyaloclastite breccias. The upper stage (mostly explosive and terrestrial) produced normal pyroclasts. Stratovolcanic volcanism is well preserved in the upper stage.

The volcanic forms of Pliocene to Quaternary alkali basaltic volcanic rocks in southern Slovakia that were described by $\mathrm{V}$. Konečný and J. Lexa (CSFR) are cinder and scoria cones, lava flows, lava plateaus. maars. diatremes, lava necks, and dikes. Detailed descriptions of volcanological research on individual volcanic features in Bohemia were given by V. Cajz (CSFR) on Podhorní vrch Hill and by P. Hradecký (CSFR) on the Komorní Hưrka and Źelezná Hůrka cinder cones.

Melilitic rocks, especially polzenites and related melilite-bearing rocks, have become a subject of increasing interest in recent years, among other reasons because of their relationship to uranium mineralization in northern Bohemia. The results of petrological and geochemical research in classic regions (the upper course of the Ploučnice River, the type locality of polzenite) were described at the symposium by J. Ulrych, E. Pivec, J. Rutšek, and P. Povondra (CSFR), who demonstrated the genetic relationship of the rocks studied to the $\mathrm{CO}_{2}$-rich ultramafic magma. This magma originated by low percent melting of metasomatized. incompatible element-enriched mantle peridotite. The melilitic rocks belong to the continental intraplate ultramafic peralkaline magmatism of the bimodal type (polzenite-phonolite association).

Trachytes and phonolites were discussed in the contributions of W.M. Bausch (Germany), P. Machek (CSFR). D. Matýsek (CSFR), and N. Krutský (CSFR). Bausch and others found centrosymmetrical relationships in the rocks of the Rhön region (Hes- 
sen to Bavaria, Germany), which are reflected in the geographical positions of the volcanic rocks, in their chemistry, and in the composition of the pyroxenes and apatites. Machek and Matýsek used mathematical and statistical methods to evaluate values from more than 190 chemical analyses of neovolcanic trachytic and phonolitic rocks in the Bohemian Massif, and they divided them into four geochemically defined groups. The presentation by Krutský dealt mainly with the practical utilization of phonolites in the glass and ceramics industries, including future applications such as building stone, crushed aggregate, stonemason works, and decorative stones.

Alkaline lamprophyres were discussed in a number of contributions by J. Souček (CSFR), B. Gruner (Germany), D. Jung (Germany), and J. Ulrych and others (CSFR). These lamprophyres are especially common in the Ceské Středohoří Mountains and in the Rhine graben (Kaiserstuhl, Germany). In addition, they have been studied in the Rhön region, in the Delitzsch near Leipzig, in northeastern Moravia, and in
Hungary. They consist mostly of camptonites (Ceské Středohoří Mountains and Kaiserstuhl) or transition types to ultramafic lamprophyres (northeastern Moravia and Hungary).

Alkaline plutonites were discussed in only a small number of lectures. G.G. Jakab (Romania) gave a survey of the petrogenesis of the alkaline massif of Ditrau in Romania, and T. Andersen (Norway) and H. Sørensen (Denmark) discussed the crystallization and metasomatism of nepheline syenite enclaves in an alkaline granite pluton in the Oslo rift. S. Kumar and V. Vilinovič (CSFR) reported on microgranitoid enclaves within Hodruša Granodiorites (western Carpathians).

Special subjects were discussed in the works of M. Mihaljevic (CSFR) on the volcanic pipe on Linhorka Hill near Třebenice, U. Schreiber (Germany) on the basaltic "Sonnebrand," and J. Rejl and S. Seic (CSFR) on a study of volcanic rocks using digital-image processing of satellite and geophysical data. V. von Seckendorf (Germany) studied the potassium-rich Permian volcanic rocks (potassic trachytes) of the Saar-Nahe
Basin of southwestern Germany, and D.R. Bowes (Great Britain) and J. Kosler (CSFR) carried out a geochemical comparison of the subvolcanic appinite suite of the British Caledonides and the durbachite suite of the central European Hercynides. The distribution of rare-earth elements in fenites and feldspathized rocks from the Cistá ring structure were described by L. Kopecký, Jr., and L. Kopecký, Sr. (CSFR).

The 2 days of lectures were followed by a 3-day excursion to northern and western Bohemia. The participants traveled through the Tertiary volcanism of this region, where type localities exist for rocks such as polzenite, modlibovite, vesecite, gauteite, and rongstockite, whose names are part of the classification systems of magmatic rocks. The volcanic rocks of the classical Ceské Středohoří Mountains were, naturally, the subject of the greatest interest. $\square$

\section{Jiř̃ Souček}

Department of Petrology

Charles University

Albertov 6

12843 Prague, Czechoslovakia

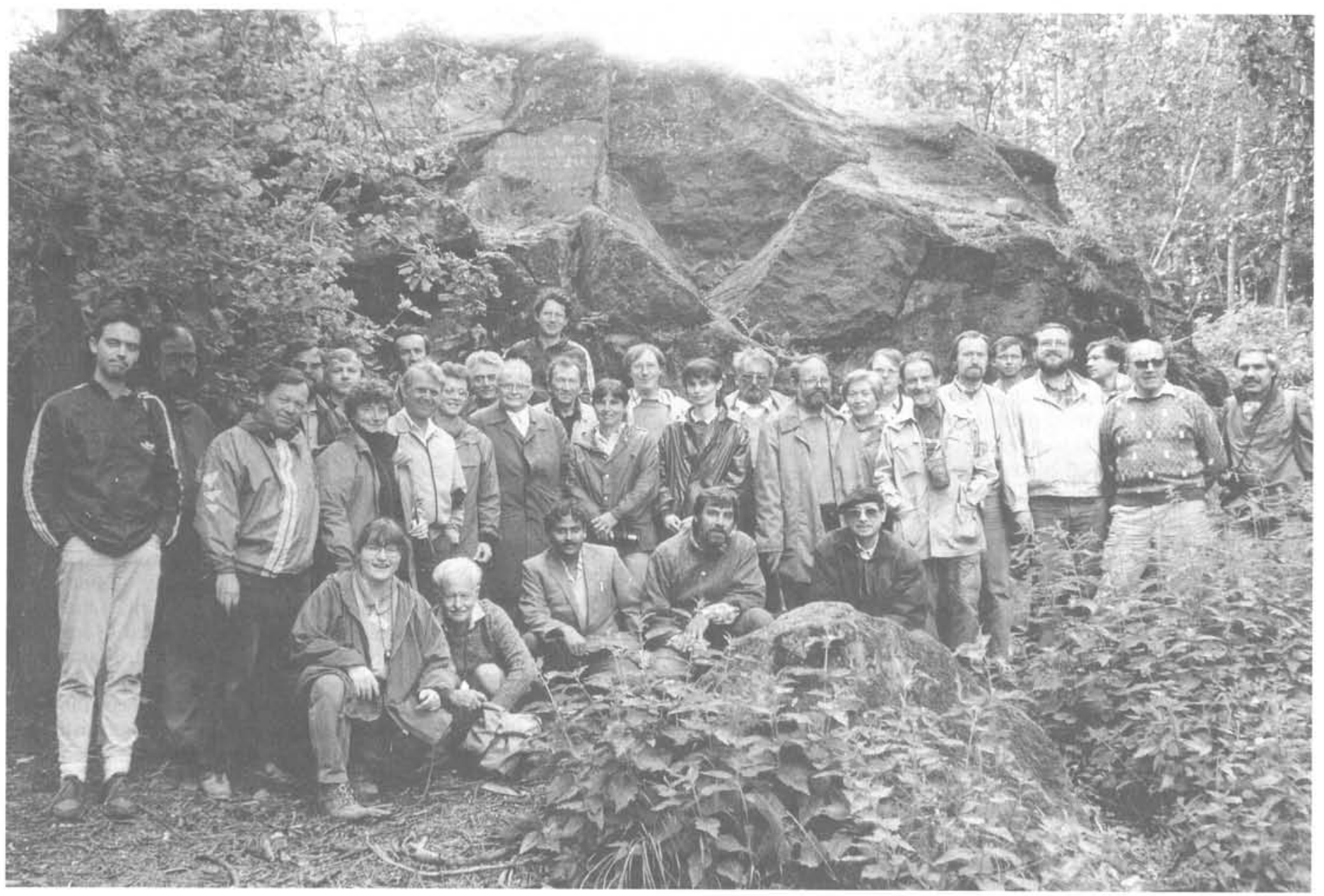

Figure 1.-Members of the postsymposium excursion at the volcano Komorni Hürka near Cheb, western Czechoslovakia. 


\section{John Ramsay Meeting: Geometry of Naturally Deformed Rocks}

\section{Zurich, Switzerland, 9-11 September 1991}

About 300 structural geologists gathered in the Geologisches Institut of Eidgenössische Technische Hochschule (ETH), Zürich, in September 1991 to honor Professor John G. Ramsay at a meeting on the "Geometry of Naturally Deformed Rocks." Although most of John's former students and colleagues were at the meeting, many others also came from a wide variety of countries, a vivid testimony to his profound influence on the international community of structural geologists. Despite a conference title emphasizing the geometrical aspects of structures, much more was offered, including many lively debates on deformation processes. However, the word "geometry" in the title did remind most speakers of two important facets of structural geology. Firstly, without accurate three-dimensional descriptions, it is not possible to speculate about the origins of structures, and secondly, and equally importantly, it is commonly the geometry of naturally occurring structures that gives them their aesthetic appeal. The beauty of many structures - and the power of that beauty to fire the imagination into thinking about the origins of phenomena-is a theme that John Ramsay has highlighted more than once in the past. Several of the speakers at Zürich warmed to the appeal of aesthetics and delighted the audience with their stunning color slides and imaginative diagrams. Excellent graphics and photographs also characterized many of the poster presentations, which were twice as numerous as the talks.

Because extended abstracts of the talks and posters presented at Zürich are available in Mitteilungen aus dem Geologischen Institut der ETH und der Universität Zürich, Neue Folge, 239b, and because selected papers will appear in a forthcoming special double issue of the Journal of Structural Geology, this report does not catalog the scientific content of the meeting. Rather, some impressions are given of its style and tone. Nearly 50 talks were given in 3 days, and in addition, long periods were available between some of the talk sessions for viewing approximately 100 posters and talking to their authors. In John Ramsay's opinion, many of the posters were of an unusually high standard. Perhaps posters should be given a higher status at many meetings? They are an ideal medium for presenting large quantities of complex data, and they allow those who are not fluent in the language of the conference to make an impact that is not dependent on verbal skill. As a further benefit, the

formal meeting in Zürich was preceded and succeeded by outstandingly stimulating and athletic Alpine traverses led by John Ramsay.

In addition to the scientific sessions, two occasions focused on the more personal aspects of the life of a structural geologist. Paul Hancock (University of Bristol, Chair of the UK's Tectonic Studies Group) congratulated John Ramsay on his founding in 1970 the Tectonic Studies Group (TSG) of the Geological Society of London. Although not the first such specialists group, Australian geologists having formed the very first one a few years earlier, the TSG exerted a powerful influence on the world's structural community. Especially influential have been its annual meetings held in December when, particularly during the 1970 s, many new ideas first were aired fully before large audiences. At successive meetings, John and his coworkers consistently presented fresh thinking about how to interpret common phenomena such as ductile shear zones, growth fibers in veins, and pressure solution seams. After the founding of the TSG in the UK, other structural and tectonic groups emerged in other countries. Now, under the guidance of Susan Treagus, an umbrella organization known as the International Association of Structural and Tectonic Geologists has come into being. Robert Shackleton (Open University, UK) paid tribute to John Ramsay as a warm friend and a renaissance man who is an accomplished cello player and a poet. "Geolities," a 50-page book of John's verses on geological topics, cockney crap, and people and places, was included in the participants' registration packages at Zürich. Robert emphasized the affection that all those who know John have for him, as well as commenting on his lack of pomposity and his ability to deflate others who possess that attribute in good measure. Mike Coward (Imperial College, UK), on behalf of John's former colleagues and students, thanked him for being both an inspiring teacher and a stimulating companion. Mike highlighted John's love of fieldwork and his ability to teach people to use their eyes. Under John's leadership, many structural geologists have come to know the beauties and intricacies of the Scottish Highlands, the Alps, and the Himalayas.

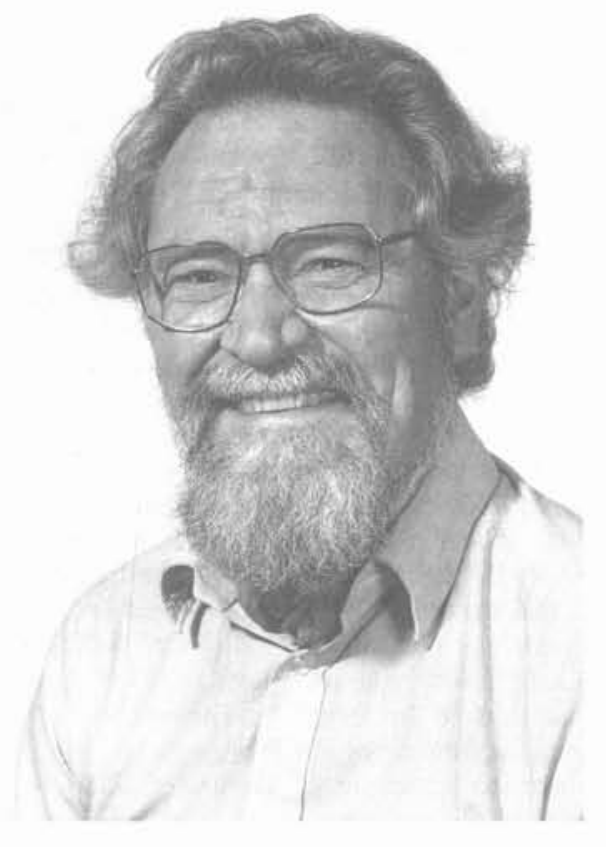

Professor John G. Ramsay

Martin Casey and Dorothee Dietrich, (Switzerland) who convened the meeting, are to be congratulated on their organizational skills and for arranging a lively social program that included an icebreaker reception at which wine appeared to be unlimited, despite the best efforts of thirsty structural geologists. Following the conference dinner, John Ramsay responded to the tribute paid to him the previous day by reminiscing and wittily outlining his geological philosophy. He spoke with feeling about the influence that his father and others have had on his career as a geologist and, briefly, as a bandsman during military service. John's enthusiasm for both music and geology are clearly as alive today as they were 40 years ago. $\square$

Paul L. Hancock

University of Bristol, UK

(Secretary General, Commission on Tectonics) 